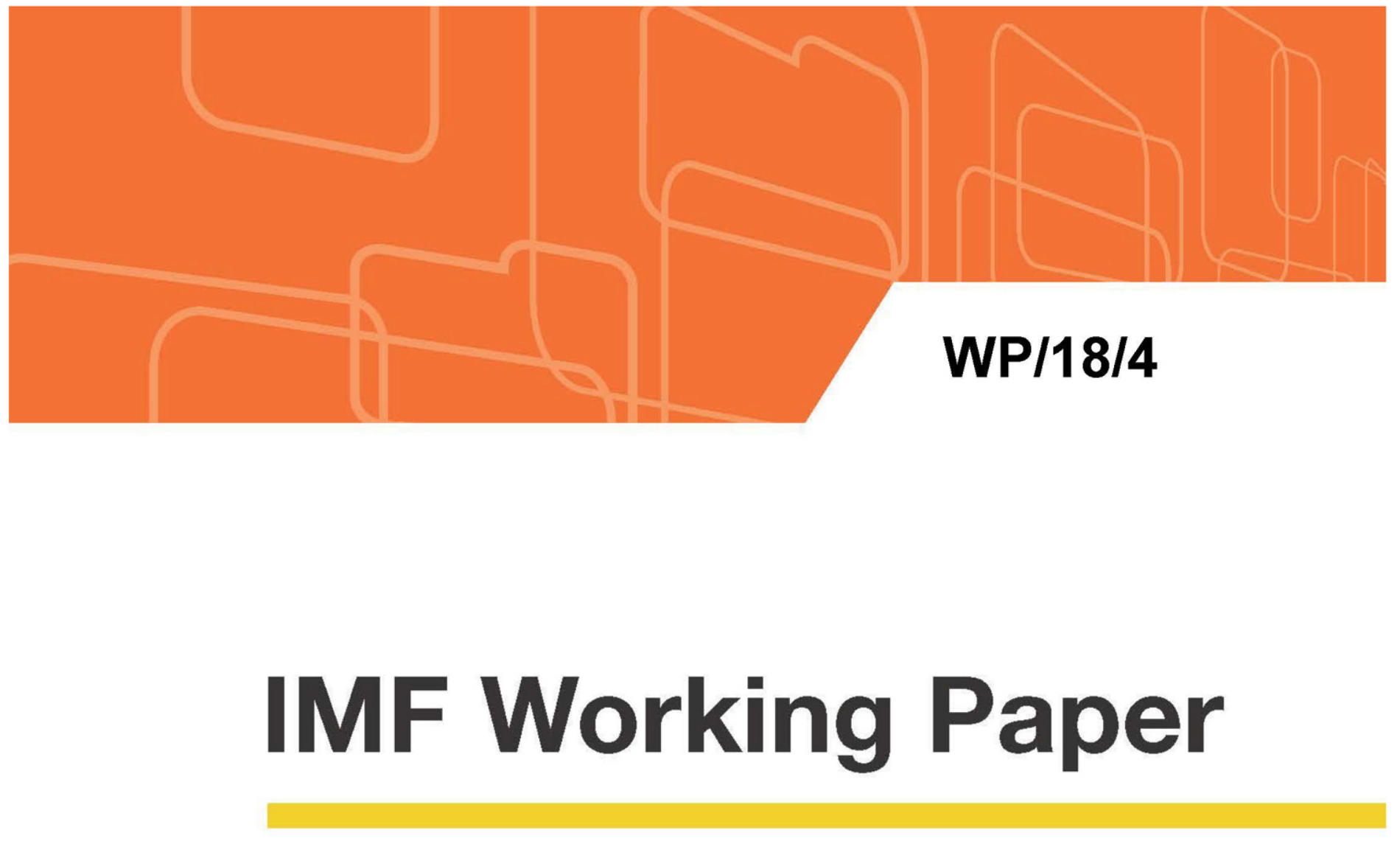

\title{
Uncertainty and Cross-Border Banking Flows
}

by Sangyup Choi and Davide Furceri

IMF Working Papers describe research in progress by the author(s) and are published to elicit comments and to encourage debate. The views expressed in IMF Working Papers are those of the author(s) and do not necessarily represent the views of the IMF, its Executive Board, or IMF management. 


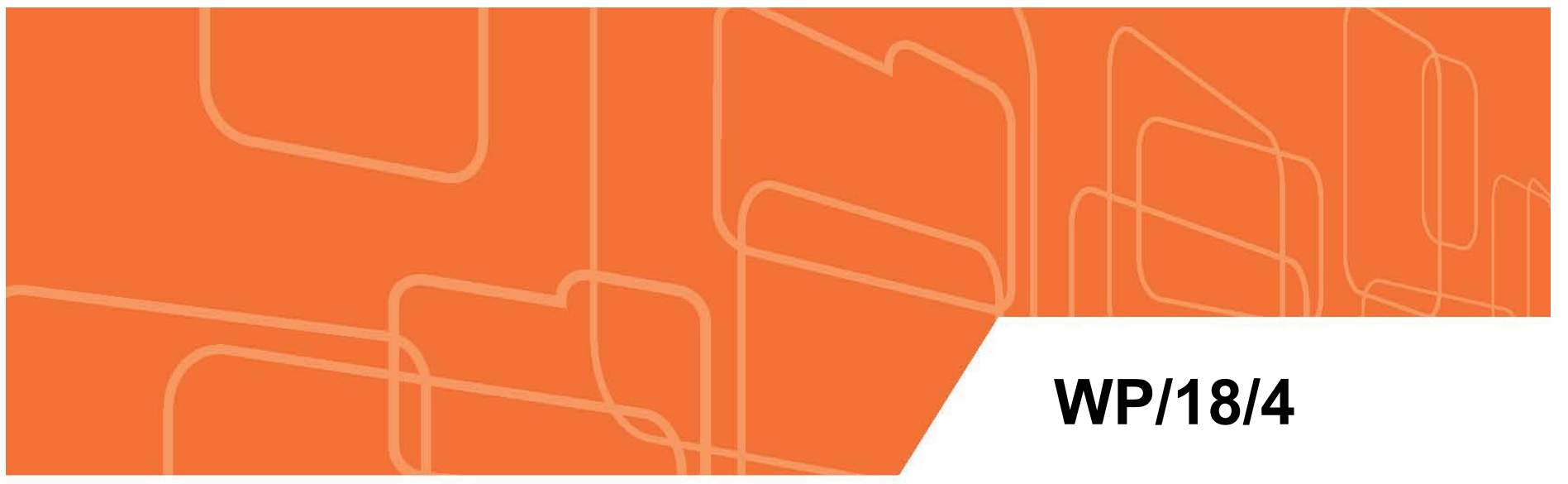

\section{IMF Working Paper}

\section{Uncertainty and Cross-Border Banking Flows}

by Sangyup Choi and Davide Furceri

IMF Working Papers describe research in progress by the author(s) and are published to elicit comments and to encourage debate. The views expressed in IMF Working Papers are those of the author(s) and do not necessarily represent the views of the IMF, its Executive Board, or IMF management.

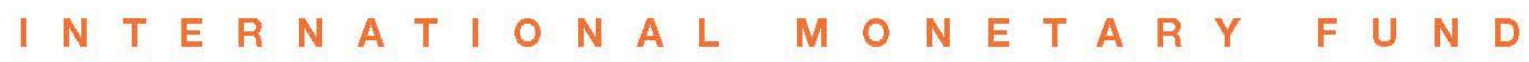




\title{
IMF Working Paper
}

\author{
Research Department
}

\section{Uncertainty and Cross-Border Banking Flows*}

Prepared by Sangyup Choi and Davide Furceri

Authorized for distribution by Chris Papageorgiou

January 2018

\begin{abstract}
IMF Working Papers describe research in progress by the author(s) and are published to elicit comments and to encourage debate. The views expressed in IMF Working Papers are those of the author(s) and do not necessarily represent the views of the IMF, its Executive Board, or IMF management.
\end{abstract}

\begin{abstract}
While global uncertainty — measured by the VIX - has proven to be a robust global "push" factor of international capital flows, there has been no systematic study assessing the role of country-specific uncertainty as a key (pull and push) factor of international capital flows. This paper tries to fill this gap in the literature by examining the effects of country-specific uncertainty shocks on cross-border banking flows using the confidential Bank for International Settlements Locational Banking Statistics data. The dyadic structure of this data allows to disentangle supply and demand factors and to better identify the effect of uncertainty shocks on cross-border banking flows. The results of this analysis suggest that: (i) uncertainty is both a push and pull factor that robustly predicts a decrease in both outflows (retrenchment) and inflows (stops); (ii) global banks rebalance their lending towards safer foreign borrowers from local borrowers when facing higher uncertainty; (iii) this rebalancing occurs only towards advanced economies (flight to quality), but not emerging market economies.
\end{abstract}

JEL Classification Numbers: F21, F32, F42

Keywords: uncertainty, cross-border banking flows, sudden stops, retrenchment, portfolio rebalancing, flight-to-quality.

Author's E-Mail Address: sangyupchoi@gmail.com, dfurceri@,imf.org

\footnotetext{
* The authors are grateful to You Suk Kim, Ling Zhu, and Yevgeniya Korniyenko for useful suggestions. Suhaib Kebhaj provided excellent research assistance. The opinions expressed herein are those of the authors and do not necessarily reflect those of the IMF, its member countries or its policy. The usual disclaimer applies and any remaining errors are the authors' sole responsibility.
} 


\section{Contents}

I. Introduction $\underline{4}$

II. Data

III. Methodology $\quad \underline{10}$

IV. Empirical Findings $\quad \underline{12}$

A. Baseline Results ..................................................................................... 12

B. Robustness Checks........................................................................................ 15

C. Mechanisms at play: Rebalancing channel of global banks .................................17

V. Conclusions $\quad \underline{22}$

References $\quad \underline{24}$

List of Figures

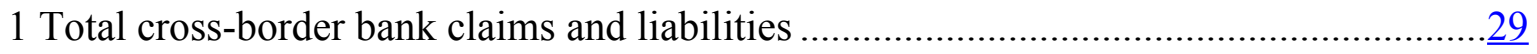

2 Examples of the bilateral cross-border bank claims and liabilities: a reporter-counterparty pair

\section{List of Tables}

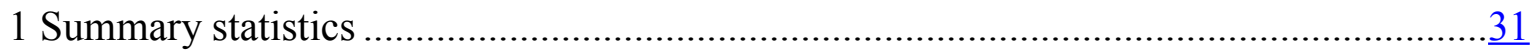

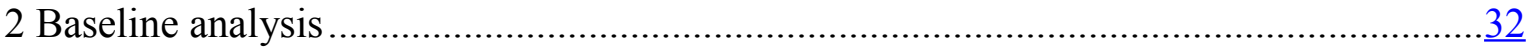

3 Link to the previous studies: Emerging market economies only ................................33

4 Robustness check: Alternative measure of uncertainty (economic policy uncertainty) ... $\underline{34}$

5 Robustness check: Alternative measure of uncertainty (idiosyncratic stock market

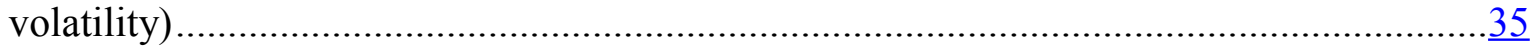

6 Robustness check: Before and after the Global Financial Crisis ................................ $\underline{36}$

7 Robustness check: Euro area vs. non-euro area countries ...........................................

8 Rebalancing between local and cross-border claims ................................................

9 Rebalancing between local and cross-border claims: Before and after the Global Financial

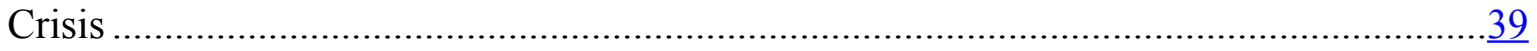

10 Rebalancing between local and cross-border claims: IV approach ........................... 40

11 Rebalancing between local and cross-border claims: Safe vs. risky borrowers ............. 41

\section{Appendix}

A Additional Figures and Tables $\quad \underline{42}$

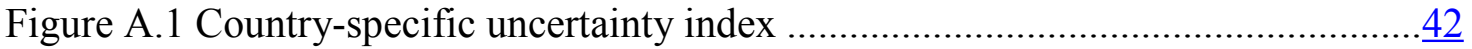

Table A.1 Event classification ...........................................................................

Table A.2 List of countries in the final sample ...............................................4 
Table A.3 Before and after the Global Financial Crisis: Economic policy uncertainty...

Table A.4 Rebalancing between local and cross-border claims: Alternative measure of uncertainty (idiosyncratic stock market volatility) ..........................................

Table A.5 Rebalancing between local and cross-border claims: IV approach with alternative measures of uncertainty

B Additional exercise on the rebalancing channel of global banks

Table B.1 Rebalancing between domestic and cross-border lending: Using an alternative share of cross-border claims .$\underline{50}$ 


\section{INTRODUCTION}

Between the early 1990 and the Global Financial Crisis (GFC), the global economy has witnessed a marked increase in cross-border banking flows. It is therefore not surprising that many studies have tried to examine the driving (push and pull) factors of this increase (Cetorelli and Goldberg, 2011; Kalemli-Ozcan et al, 2013; Kleimeier et al., 2013; Minoiu and Reyes, 2013; Cerutti et al., 2015b; Cerutti et al., 2017; Correa et al., 2017).

Given that cross-border bank lending activity sharply slowed down during the GFC together with heightened uncertainty worldwide, it is timely to ask the role of uncertainty shocks in explaining the cross-border banking flows. Despite the fact that literature has increasingly focused on the effect of uncertainty on macroeconomic outcomes, an analysis of uncertainty shocks in the international context have received less attention (Carrière-Swallow and Céspedes, 2013; Gourio et al., 2013; Fogli and Perri, 2015; Bernal, 2016; Choi, 2017; Choi, forthcoming). In particular, while the VIX - a measure of global uncertainty or global risk aversion- has proved to be an important push factor of international capital flows (Milesi-Ferretti and Tille, 2011; Forbes et al., 2012; Fratzscher, 2012; Ahmed and Zlate, 2014; Bruno and Shin, 2014; Passari and Rey, 2015; Rey, 2015), only few studies have examined cross-country hetereogeneity in uncertainty to explain international capital flows (Gauvin et al., 2014; Gourio et al., 2015; Julio and Yook, 2016). This paper contributes to this literature by providing a first analysis - to the best of our knowledge — of the effects of uncertainty shocks on cross-border banking flows. ${ }^{1}$

Identifying the effect of uncertainty shocks on cross-border banking flows is challenging because it is hard to separate between credit demand and credit supply factors. For example, to properly quantify the effect of uncertainty shocks on cross-border lending one would have to control for all possible macroeconomic shocks affecting credit demand in recipient countries. We overcome this challenge by using data on bilateral cross-border bank claims and liabilities from the BIS LBS database. In particular, the dyadic structure of this

\footnotetext{
${ }^{1}$ Previous studies on uncertainty and international capital flows have examined total capital flows (Gourio et al., 2015), portfolio flows (Gauvin et al., 2014), and FDI flows (Julio and Yook, 2016). However, none of them has exploited bilateral flow data, as we do in this paper.
} 
data allows to control for recipient country-time fixed effects - that is, any macroeconomic shock affecting credit demand - and therefore to better identify the effect of uncertainty shocks on cross-border banking flows. ${ }^{2}$

We study how global banks adjust their cross-border claims and liabilities in response to higher uncertainty in the local economy. After controlling for various macroeconomic factors affecting credit supply in source countries, we find that an increase in uncertainty in a local economy reduces both cross-border claims (retrenchment) and liabilities (stops), and this effect is economically and statistically significant. ${ }^{3}$ These findings are confirmed by using alternative proxies of uncertainty, such as the Economic Policy Uncertainty (EPU) index by Baker et al. (2016) and idiosyncratic stock market volatility purged by the VIX. In addition, despite the sharp slowdown in cross-border banking activity during the GFC, our finding is not simply driven by this influential event, as uncertainty shocks are found to have negative effects on cross-border banking activity even before the GFC.

We further contribute to the literature by analyzing global banks' portfolio rebalancing behaviors in response to heightened uncertainty. The results of this analysis suggest that the share of cross-border claims in total claims of the global banks increases when uncertainty about the local economy is higher, implying that banks rebalance their lending towards foreign borrowers, who are perceived as relatively safer. Interestingly, this portfolio rebalancing channel depends on the perceived riskiness of recipient countries: the channel oprates only for lending to advanced economies, but not emerging market economies, suggesting the existence of "flight-to-quality". Our results are also robust to an

\footnotetext{
${ }^{2}$ Our identification strategy is similar to the one used by Julio and Yook (2016) to examine the effect of heightened policy uncertainty driven by presidential elections in a recipient country on FDI flows into this economy. By limiting their analysis to FDI flows from the U.S. only, they effectively control for the supply-side effect of FDI and study how heterogeneity in uncertainty across countries affects FDI inflows into these economies.

${ }^{3}$ Forbes and Warnock (2012) define four different events regarding intertnational capital flows as follows. "Surges": a sharp increase in gross capital inflows; "Stops": a sharp decrease in gross capital inflows; "Flight": a sharp increase in gross capital outflows; and "Retrenchment": a sharp decrease in gross capital outflows. In the sixth edition of the Balance of Payments and International Investment Position Manual (BPM6), positive asset (liability) flows mean capital leaving (entering) the country on net by domestic (foreign) residents. Thus, a decrease in global banks' cross-border claims corresponds to retrenchment, while a decrease in cross-border liabilities corresponds to stops.
} 
instrument variable (IV) approach using the exogenous historical events identified by Baker and Bloom (2013).

The remainder of the paper is organized as follows. Section II describes the data on cross-border banking flows, together with data on uncertainty and various macroeconomic controls. Section III proposes the econometric methodology used in this paper to mitigate endogeneity issues and disentangle between credit demand and supply factors. Section IV presents the main results and a battery of robustness exercises. Section V concludes.

\section{DATA}

We use data on cross-border claims and liabilities from the Bank for International Settlements (BIS)' Locational Banking Statistics (LBS) as our main source. These statistics provide information about the currency composition of banks' balance sheets and the geographical breakdown of their counterparties. The LBS data capture outstanding claims and liabilities of internationally active banks located in reporting countries against counterparties residing in more than 200 countries. Banks record their positions on an unconsolidated basis, including intragroup positions between offices of the same banking group. The data is compiled following the residency principle that is consistent with the balance of payments (BOP) statistics. ${ }^{4}$

Currently, banking offices located in 46 countries, including many offshore financial centers, report the LBS. The LBS capture around 93 percent of all cross-border interbank business (Bank for International Settlements, 2017). ${ }^{5}$ The BIS LBS provides the exchangerate adjusted flows in cross-border bank claims and liabilities, while the Consolidated Banking Statistics (CBS) based on the nationality principle do not have information on

\footnotetext{
${ }^{4}$ While the data is made public by the BIS at the aggregate level, the data on bilateral claims and liabilities between reporting (source) and counterparty (recipient) countries is available to reporting central banks. Because we follow the residency principle of BPM6, we use reporting (counterparty), source (recipient), and home (foreign) countries interchangeably throughout the paper. For example, higher uncertainty at home denotes uncertainty in Mexico, not in the U.K for the British banks operating in Mexico.

${ }^{5}$ Although there is no similar estimate for the share of cross-border bank lending to non-banks in the LBS, Adjiev et al. (2017) claim that it is likely to be above 90 percent.
} 
currency breakdown. ${ }^{6}$ The adjustment for exchange rate movements is particularly important because contractions in cross-border banking flows tend to coincide with large currency movements and heightened uncertainty. Thus, ignoring the valuation effect could bias the results of the effect of uncertainty shocks on cross-border banking flows. ${ }^{7}$

As highlighted in Forbes and Warnock (2012), Broner et al. (2013), and Bruno and Shin (2014), the dramatic increase in gross capital flows has posed a challenge to the traditional approach to international finance based on net capital flows where financial flows are seen only as the counterpart to the current account. Thus, most previous studies on capital flow rely on proxies for net capital flows, which cannot differentiate between changes in foreign and domestic behaviors.

While we do not attempt to summarize the mounting literature on gross capital flows, a large body of the literature has focused on long-run trends in gross capital flows (Gourinchas and Rey, 2007; Lane and Milesi-Ferretti, 2007; Obstfeld, 2012) or gross capital flows during specific episodes (Kim and Wei, 2002; Milesi-Ferretti and Tille, 2010; Fratzscher, 2012). In contrast, our paper analyzes the cyclicalical pattern of gross capital flows, focusing on the effect of uncertainty shocks on cross-border banking flows. In this regard, the major advantage of the BIS LBS data, compared to the banking flows collected from the balance of payments statistics, is the detailed breakdown of the reported series by counterparty countries. This feature enables us to identify changes in the supply factors of banking flows from changes in demand for bank credit in counterparty countries.

Throughout the analysis, we drop offshore financial countries from our sample using the IMF classification. In our benchmark analysis - after dropping offshore financial centers - we focus on the 25 countries among the 46 reporting countries where a measure of uncertainty and major macroeconomic variables are available. Similarly, after dropping

\footnotetext{
${ }^{6}$ The adjusted change is calculated by first converting U.S. dollar-equivalent amounts outstanding into their original currency using end-of-period exchange rates, then calculating the difference in amounts outstanding in the original currency, and finally converting the difference into a U.S. dollar-equivalent change using average period exchange rates (Bank for International Settlements, 2017).

${ }^{7}$ Adjusted changes in amounts outstanding are calculated, as an approximation for flows. In addition to exchange rate fluctuations, the quarterly flows in the locational datasets are corrected for breaks in the reporting population (Avdjiev and Takáts, 2014).
} 
offshore financial centers from the list of recipient countries, we are left with the 50 recipient countries in our analysis. Following Correa et al. (2017), we also drop observations with the size of cross-border flows less than $\$ 5$ million, or with negative total outstanding claims.

Finally, to control for extreme outliers, we also winsorize the dependent variable at the one percentile. Table A.1 in the appendix lists the final sample of reporting and counterparty countries used in the analysis. It is apparent that most reporting countries are advanced economies, while counterparties are both advanced and emerging market economies, highlighting the asymmetric nature of the bilateral LBS data.

Following much of the recent literature on the link between uncertainty and the macroeconomy (for example, Bloom, 2009), we use quarterly stock market volatility as a proxy for uncertainty. ${ }^{8}$ To maximize the coverage of data, we take the realized volatility data from Baker and Bloom (2013) instead of using implied volatility. In principle, implied volatility is a better measure of uncertainty of the economy than realized volatility, as it contains forward-looking information. In practice, however, the difference is minor. ${ }^{9}$

To provide a first look at the data, we plot fluctuations in the uncertainty index with total cross-border claims and liabilities for three countries (the U.S., Germany, and Brazil) in Figure 1. Three observations stand out from this figure. First, the different scales of the yaxis in these graphs demonstrate the dominance of advanced economies in the global banking system. Compared to the U.S. or Germany, the size of cross-border banking flows into/from Brazil — one of the largest emerging market economies - is trivial. Second, the figure shows that heightened uncertainty in a local economy is often associated with a reduction in both cross-border bank claims and liabilities. ${ }^{10}$ Such a positive co-movement between the crossborder banking sector claims and liabilities is consistent with the earlier finding that gross

\footnotetext{
${ }^{8}$ The empirical distinction between risk and uncertainty is far from being clear. For example, prior studies on international capital flows often use the VIX as a measure of global risk aversion (Milesi-Ferretti and Tille, 2011; Forbes and Warnock, 2012; Bruno and Shin, 2015; Rey, 2015). We contribute to this literature by also examining the effect of economic policy uncertainty.

${ }^{9}$ For example, in the U.S., the correlation between two measures exceeds 0.9 in the period 1990:01-2014:12 (Choi, 2017).

${ }^{10}$ Gross flows can be both positive or negative because existing capital flow datasets net out disinvestment from gross asset flows and repayments from gross liabilities flows. See Avdjiev et al. (2017) for more comprehensive discussion about the commonly used capital flow datasets.
} 
capital inflows and outflows are positively correlated (Broner et al., 2013; Forbes and Warnock, 2012; Avdjiev et al., 2017). Third, the slowdown in cross-border banking flows during the GFC is at the unprecedented level in all three countries, consistent with the findings from the recent literature (Milesi-Ferretti and Tille, 2011; Cetorelli and Goldberg, 2011; Ahmed and Zlate, 2014; Cerutti et al., 2015b; Passari and Rey, 2015; Correa et al., 2017). Due to the dominance of the GFC, we also test the robustness of our findings using the pre-crisis sample.

However, looking at the aggregate cross-border banking flows alone does not account for the fact that uncertainty also reduces demand for investment and credit (Bernanke, 1983; Bloom, 2009; Christiano et al., 2014; Choi et al., forthcoming). To disentangle supply and demand factors of banking flows, we exploit the dyadic structure of the LBS data. To illustrate the dyadic structure, Figure 2 presents examples of bilateral cross-border claims and liabilities between the three countries (the U.S., Germany, and Brazil). Compared to Figure 1, Figure 2 presents some heterogeneity in the pattern of cross-border claims and liabilities among different country-pairs. At the individual country-pair, the correlation between crossborder claims and liabilities is much lower, and the cyclical pattern of the flows differs between advanced and emerging market economies. Our identification strategy exploits this heterogeneity.

Because the LBS data structure allows us to control for time-variant unobserved factors in recipient countries, we need to control for macroeconomic variables in source countries to identify the causal effect of uncertainty shocks on the cross-border banking flows. Based on the extensive literature on international capital flows (Calvo, 1996; MilesiFerretti and Tille, 2011; Forbes and Warnock, 2012; Fratzscher, 2012; Broner et al., 2013; Kleimeier et al., 2013; Ghosh et al., 2014; Cerutti et al., 2015b; Cerutti et al., 2017; Correa et al., 2017), we consider the following set of controls: real GDP growth, stock market growth, the inflation rate, the monetary policy rate, nominal exchange rate growth, ${ }^{11}$ private credit growth, and the external debt to GDP ratio.

\footnotetext{
${ }^{11}$ An increase in the nominal exchange rate denotes the depreciation of local currencies against the U.S. dollar.
} 
We include central bank policy rates to capture a standard bank lending channel of monetary policy in the global context (Bruno and Shin, 2014; Rey, 2015; Correa et al., 2017) - we use interbank rates when policy rates are not available. To the extent that monetary policy stance and uncertainty are systematically related (Bekaert et al., 2013), controlling for policy rates is key. Similar to Bloom (2009), we further control for stock market returns to disentangle second-moment shocks—our baseline measure of uncertainty - from first-moment shocks to the stock market. Table 1 presents the summary statistics of the variables used in the analysis. Notably, the average growth rates of crossborder claims and liabilities are about three percent, while their standard deviations exceed 40 percent, similar to the finding of Correa et al. (2017). Our finding is also consistent with the earlier finding that banking flows are the most volatile component of cross-border capital flows (Milesi-Ferretti and Tille, 2011; Ahmed and Zlate, 2014).

\section{Methodology}

Any empirical investigation of factors affecting bank credit must note that variations in the volume of credit reflect not only the supply-side but also the demand-side factors because demand for credit is also responsive to changes in macroeconomic conditionsincluding uncertainty — which, in turn, affects the expected return and risks on investment projects. We exploit the dyadic structure of the LBS data (that is, multiple reporting countries linked to multiple counterparties), to control for unobserved time-variant factors in a counterparty country, thereby effectively controlling for all possible demand-side factors. This approach delivers a clear identification of the role of uncertainty as both a push and pull factor of cross-border banking flows.

To gauge the effects of higher uncertainty in a local economy on determining crossborder claims (i.e., a push factor), we first estimate the following equation:

$$
\Delta L_{i, j, t}=\alpha_{j, t}+\beta X_{i, t-1}+\gamma U N C_{i, t-1}+\varepsilon_{i, j, t},
$$

where $i$ and $j$ respectively indicate the reporting ('source') and counterparty ('recipient') countries, and $t$ denotes time. Following Bruno and Shin (2014), our main dependent variable $\Delta L_{i, j, t}$ denotes the quarterly growth (log difference) in cross-border claims of banks in a 
country $i$ in a country $j ; X_{i, t}$ is the set of group of macroeconomic controls described earlier. $\alpha_{j, t}$ are recipient country-time fixed effects, included to control for any macroeconomic shocks affecting recipient countries, including external and idiosyncratic recipient-specific shocks as well as indirect impact of uncertainty trough other recipient countries. In addition, the inclusion of counterparty-time fixed effects effectively maximizes the sample size of our analysis because many of counterparty countries do not necessarily have data on every control variable; and $\gamma$ is the coefficient of our interest. A negative (positive) $\gamma$ indicates that global banks decrease (increase) cross-border lending in an absolute term when the local economy faces higher uncertainty. Following Bruno and Shin (2014), all explanatory variables are lagged by one-quarter to reduce reverse causality concern. We adopt the most conservative clustering setup by clustering standard errors at the reporting and counterparty country-pair levels.

One main advantage of the BIS LBS data is that the currency composition of crossborder claims and liabilities is available so that cross-border banking flows expressed in the U.S. dollars are adjusted for movements in exchange rates. To the extent that heightened uncertainty episodes coincide with large fluctuations in the exchange rate (De Bock and Filho, 2015; Choi, 2017; Choi, forthcoming), it is crucial to obtain a real measure of crossborder flows. Because the BIS LBS only reports the exchange rate-adjusted flows, we reconstruct the stock of the cross-border claims $\left(L_{i, j, t}\right)$ by adding the exchange rate-adjusted flows to the initial stock and take the log difference to obtain the growth rate $\Delta L_{i, j, t}$.

Similarly, we also analyze the effect of higher uncertainty in a source country on cross-border liabilities of its banking sector, by replacing the stock of the cross-border claims $\left(L_{i, j, t}\right)$ in equation (1) with the stock of the cross-border liabilities $\left(B_{i, j, t}\right)$ :

$$
\Delta B_{i, j, t}=\alpha_{j, t}+\beta X_{i, t-1}+\gamma U N C_{i, t-1}+\varepsilon_{i, j, t} .
$$


Again, we focus on a reporting country only due to the asymmetry in the LBS data. ${ }^{12}$ In this case, a negative (positive) $\gamma$ indicates that global banks receive less (more) crossborder lending in an absolute term when their home country faces higher uncertainty.

\section{EMPIRICAL FINDINGS}

\section{A. Baseline results}

Table 2 shows the results obtained by estimating equation (1) and (2). We discuss the results of estimating equation (1) first, and then we present the results of estimating equation (2). Due to the limited availability of some control variables, we start presenting a specification which includes only real GDP growth, stock market growth, the inflation rate, the policy rate, and nominal exchange rate growth as controls.

The signs of control variables are largely consistent with the previous findings regarding the determinants of international capital flows. For example, once controlling for credit demand, global banks in a country with higher economic growth lend more to foreign borrowers. It is because the health of the banking system improves with the domestic economic condition, enabling them to expand lending activity. Domestic monetary policy tightening has a positive effect on gross cross-border claims, which is consistent with the finding of Correa et al. (2017). Although the conventional bank lending channel of monetary policy implies that tighter monetary policy in a local economy induces banks to reduce their lending, the economic expansion in the local economy accompanied by monetary policy increases cross-border lending. ${ }^{13}$ The depreciation of local currencies with respect to the U.S. dollar is associated with a slowdown in cross-border bank lending, which is consistent with the risk-taking channel of Bruno and Shin (2015). Nevertheless, the effect is not robust in our sample.

\footnotetext{
${ }^{12}$ In principle, we could replace counterparty-time fixed effects with reporter-time fixed effects and study the role of higher uncertainty in counterparty countries. However, counterparty countries often include emerging and developing economies where various macroeconomic variables are not necessarily available at a quarterly frequency.

${ }^{13}$ Perhaps, a more interesting question regarding the bank lending channel of monetary policy is to check whether global banks shift their lending towards domestic borrowers from their foreign counterparts when facing tighter monetary policy in a local economy. We discuss this channel in the later section.
} 
Importantly, higher uncertainty in a home country reduces gross cross-border bank claims (retrenchment), and this effect is both economically and statistically significant. For example, an increase in the level of uncertainty from the historical median to the level observed during the GFC is associated with a reduction in cross-border claims of 1.6-2.8 percentage points. In column (II) and (III), we include additional control variables such as private credit growth and external debt to GDP. While an increase in domestic private credit growth is associated with an increase in cross-border bank lending, this effect is not statistically significant. In contrast, the share of external debt in GDP is negatively related to cross-border lending activity, and this effect is highly statistically significant. Despite the reduced sample size due to the limited availability of these variables, the effect of domestic uncertainty shocks on cross-border bank lending remains broadly unchanged.

In column (IV) to (VI), we summarize the same set of results for cross-border liabilities of a reporting country. In other words, we examine whether higher uncertainty in a local country reduces gross inflows to the domestic banking sector (stops). In column (IV), higher real GDP growth and policy rates in the reporting countries are associated with an increase in cross-border bank liabilities, although the latter is no longer statistically significant. Importantly, the sign of uncertainty is negative and statistically significant, suggesting that uncertainty reduces gross inflows to the domestic banking sector.

\section{Link to the previous studies}

To the best of our knowledge, there are only a few studies on the link between uncertainty and capital flows using country-specific uncertainty. For example, using a large panel of emerging countries, Gourio et al. (2015) find that an increase in domestic uncertainty, measured by the realized stock market volatility in each emerging economy, decreases capital inflows (stops) and capital outflows (retrenchment). ${ }^{14}$ Gauvin et al. (2014) study how uncertainty about macroeconomic policies in advanced countries spills over to emerging market economies by analyzing bond and equity inflows to emerging market economies. These studies rely on either balance of payment data (Gourio et al., 2015) or the

\footnotetext{
${ }^{14}$ Forbes et al. (2012) find a similar effect of the VIX on the probability of sudden stop and retrenchment episodes of emerging.
} 
Emerging Portfolio Fund Research (EPFR) data aggregated at the recipient country level (Gauvin et al., 2014), which do not provide information on a source of capital inflows to emerging market economies. Thus, their estimation still suffers from the reverse causality or omitted variable bias. Our approach improves the identification by exploiting the dyadic structure of the BIS LBS.

We compare briefly whether our finding is consistent with these previous studies focusing on emerging market economies using different data. First, Gourio et al. (2015) analyze total capital flows including direct investment, portfolio, and other flows into/from emerging market economies, while we focus mainly on the cross-border banking flows from (large) advanced economies (column (I) to (III) in Table 2). Nevertheless, when we restrict our analysis to emerging market economies similarly to the sample of Gourio et al. (2015), we find a negative effect of domestic uncertainty on cross-border bank claims (shown in column (I) to (III) in Table 3). ${ }^{15}$ Not surprisingly, the size of coefficients found in Table 3 tends to be larger than that in column (I) to (III) in Table 2, implying that the negative effects of uncertainty shocks on the cross-border banking flows into emerging market economies are larger than those into advanced economies. This finding is consistent with a large body of empirical literature that capital flows into emerging market economies are more procyclical than advanced economies (Raddatz and Schmukler, 2012).

Second, to compare our results with those of Gauvin et al. (2014), we restrict the counterparty countries to emerging market economies and the report countries to advanced economies. The results in column (IV) to (VI) of Table 3 show that cross-border banking flows into emerging market economies decrease in response to uncertainty shocks in advanced economies, confirming the findings of Gauvin et al. (2014) of spillover effect of uncertainty shocks from advanced economies on portfolio inflows to emerging market economies.

\footnotetext{
${ }^{15}$ Note that the sample size is reduced substantially because most reporting countries in the BIS LBS are advanced economies.
} 


\section{B. Robustness checks}

\section{Alternative measure of uncertainty}

We have used stock market volatility as a benchmark measure of uncertainty because it is widely used, it is readily available at a high frequency, it has the longest time-series, and it allows for straightforward international comparisons. ${ }^{16}$ However, stock market volatility also captures investor's risk aversion (Bekaert et al., 2013) other than macroeconomic uncertainty. Moreover, high cross-country correlation in stock market volatility due to the contagion in international financial markets (Choi, 2017) makes identification of the shocks difficult. ${ }^{17}$ Following recent empirical studies, we use the economic policy uncertainty (EPU) index constructed by Baker et al. (2016) to complement the measure of uncertainty based on financial market data (Bachmann et al., 2013; Bernal, 2016; Bordo et al., 2016; Choi, 2017; Ozturk and Sheng, 2017; Choi et al., forthcoming). ${ }^{18}$ Given that the two indices measure uncertainty about different aspects of the economy, this sensitivity test complements the baseline analysis using stock market volatility.

The EPU index is based on the domestic newspaper coverage frequency of policyrelated economic uncertainty, thereby mitigating the concerns mentioned above. Baker et al. (2016) conduct comprehensive searches of newspapers for relevant terms, such as "uncertain" or "uncertainty"; "economic", "economy” or commerce"; and policy-relevant terms, such as "central bank", "deficit", "trade policy", or "ministry of finance". For countries other than Australia, Canada, the UK, and the US, they conduct searches in the native language of the newspaper for relevant terms. However, this index is available for only 15 countries (Australia, Brazil, Canada, Chile, France, Germany, India, Italy, Japan, Korea, Netherlands, Spain, Sweden, the United Kingdom, and the United States) in our sample. Figure A.1 in the appendix presents quarterly stock market volatility for 25 countries

\footnotetext{
${ }^{16}$ For example, other uncertainty measures based on survey data (Bachmann et al., 2013; Morikawa, 2016) are not necessarily comparable between countries. Cross-sectional measures such as the dispersion of firm-level sales, employment, and productivity are often available for a much shorter period.

${ }^{17}$ For example, Bloom (2017) claims that the U.S economy exports its uncertainty to the rest of the world. Due to such a strong dominance of the U.S. in shaping global uncertainty, we repeat our analysis by dropping the U.S. and find quantitatively similar results.

${ }^{18}$ We download the historical version of the EPU index (Baker et al., 2016) from www.policyuncertainty.com.
} 
together with the economic policy uncertainty index for 15 countries. The correlation between stock market volatility and economic policy uncertainty is far from perfect. The average correlation of the 15 countries is only 0.38 , and the correlations range from 0.03 (Sweden) to 0.76 (Brazil).

The results obtained re-estimating equation (1) and (2) using the EPU index are reported in Table 4. The negative effect of uncertainty shocks on the growth of cross-border bank claims and liabilities is still significant and quantitatively similar to the baseline analysis.

As an additional robustness check and to alleviate the concern regarding the contagion in international financial markets (Bloom, 2017; Choi, 2017; Ozturk and Sheng, 2017), we use the idiosyncratic stock market volatility of each source country that is purged of global uncertainty (i.e., the VIX). In particular, we proceed in two steps. First, we regress country-specific stock market volatility on the contemporaneous value of the VIX and take the residuals - we refer to these residuals as idiosyncratic uncertainty. Second, we replace the original stock market volatility with these residuals in equation (1) and (2). The results reported in Table 5 confirm the significantly negative effect of uncertainty shocks on the growth of cross-border bank claims and liabilities.

\section{Before and after the global financial crisis}

As demonstrated in Figure 1 and 2, a decline in cross-border banking flows during the GFC is unprecedented. Thus, the inclusion of this extreme event might have driven our empirical finding. It is also possible that quantitative easing $(\mathrm{QE})$ in advanced economies might have altered the way uncertainty affects international capital flows. For example, Ahmed and Zlate (2014) and Fratzscher et al. (2016) find a positive effect of the U.S. unconventional monetary policy on capital flows into emerging market economies. To check whether our results are robust to these events, we split the sample into the pre-(1995Q12007Q2) and the post-(2007Q3-2012Q4) GFC, and re-estimate equation (1) and (2) using both measures of uncertainty (stock market volatility and economic policy uncertainty). To maintain the sample size of the first sub-sample, we exclude the additional control variables of private credit growth and external debt to GDP in this exercise. 
Table 6 summarizes the results from the sub-sample analysis using stock market volatility as a measure of uncertainty. The results using the EPU index are shown in Table A.3 in the appendix. One interesting observation is the decrease in the size and the significance of the policy rate after the GFC. It is likely an outcome of the constrained conventional monetary policy in most advanced economies and the emerging role of QE (Fratzscher et al., 2016). An increase in uncertainty in a local economy-whether it is measured by stock market volatility or EPU—robustly predicts a slowdown in cross-border bank claims and liabilities before and after the GFC.

\section{The role of the euro area in driving cross-border banking flows}

Given the central role of the European global banks in global banking flows (Cetorelli and Goldberg, 2011; Shin, 2012; Ivashina et al., 2015), an interesting question is whether the behaviors of global banks residing in the euro area differ from those of global banks outside the euro area. To answer this question, we split the 25 reporting countries into euro and noneuro area countries and repeat the analysis. Table 7 shows that the negative effect of domestic uncertainty on cross-border banking flows exists in both euro area and non-euro area countries, although the effect is larger and more precisely estimated in euro area economies. ${ }^{19}$ In addition, the effect on cross-border claims is larger and more precisely estimated than cross-border liabilities.

\section{Mechanism at play: Rebalancing channel of global banks}

So far, we have found robust evidence that higher uncertainty in a reporting country reduces its global banks' cross-border claims (outflows) and liabilities (inflows), thereby proving uncertainty as both a push (supply) and pull (demand) factor of cross-border banking flows. This finding alone, however, does not provide direct evidence on whether global banks rebalance the composition of their lending in response to higher uncertainty in a local economy because banks are also known to reduce their lending to domestic borrowers when facing higher uncertainty (Baum et al., 2002; Bordo et al., 2016; Raunig et al., 2016).

\footnotetext{
${ }^{19}$ Some control variables lose their statistical significance compared to column (III) and (VI) in Table 1, probably due to the smaller sample size. Because of a single currency and common monetary policy in the euro area since 1999, we cannot estimate these variables for the euro area sample.
} 
As long as global banks operate across different markets, it is possible that they find foreign borrowers relatively more attractive when facing higher uncertainty in a local economy. For example, Fogli and Perri (2015) find some evidence that an increase in relative uncertainty at a home country is associated with an increase in net foreign assets due to the precautionary saving motives. However, the analysis of the domestic banking system alone cannot test the hypothesis above because not all banks in the system can engage in crossborder lending. To the extent that large global banks in the BIS LBS are able to extend credit across the border without much friction (Bruno and Shin, 2015), we can identify the so-called rebalancing channel of global banks in response to uncertainty shocks.

We test the rebalancing channel by creating a new dependent variable to proxy the share of cross-border claims in total claims by global banks. Unfortunately, the BIS LBS do not provide historical data on total domestic claims of the global banks in a reporting country. ${ }^{20}$ This data limitation does not allow us to calculate the share of cross-border claims in total claims by the same set of global banks in a reporting country directly. Instead, we use local claims in foreign currencies of the global banks in a reporting country to capture the rebalancing channel of global banks between local and foreign borrowers. As long as most of cross-border claims are denominated in foreign currencies, including local claims in local currencies of the global banks in a reporting country may not necessarily improve the identification of the rebalancing channel because local lending in local currencies may be subject to a completely different mechanism from cross-border lending. ${ }^{21}$

\footnotetext{
${ }^{20}$ The BIS LBS provides the data on domestic claims of the global banks in local currencies in a reporting countries ("Q:S:C:A:TO1:D:5J:A:Country:A:5J:R" in BIS statistics code) only after 2012 (Bank for International Settlements, 2017). The BIS LBS, however, provides the historical data on local claims in foreign currencies of the global banks in a reporting country ("Q:S:C:A:TO1:F:5J:A:Country:A:5J:R"). The sum of these two is total domestic claims of the global banks in a reporting country (“Q:S:C:A:TO1:D:5J:A:Country:A:5J:R”).

${ }^{21}$ Nevertheless, we complement our analysis here by considering the fraction of cross-border claims of global banks in a reporting country to total domestic claims, which include not only global banks reported to the BIS, but all depository financial institutions from the IMF International Financial Statistics Depository Corporations Survey. The appendix B provides the detail of data construction and the estimation results, which are qualitatively similar to those considered here.
} 
Because both cross-border claims and local claims in foreign currencies are already converted to the U.S. dollar from the BIS LBS in a consistent manner, we do not need to further adjust for exchange rates. ${ }^{22}$ Thus the share of cross-border claims is computed as:

$$
S_{i, j, t}=\frac{\text { cross-border claims }_{i, j, t}}{\text { cross-border claims }_{i, j, t}+\text { local claims in foreign currencies }_{i, t}} \times 100 .
$$

We estimate the effect of uncertainty shocks on the share of cross-border claims using a specification similar to equation (1):

$$
s_{i, j, t}=\alpha_{j, t}+\beta X_{i, t-1}+\gamma U N C_{i, t-1}+\varepsilon_{i, j, t}
$$

with a positive (negative) sign of $\gamma$ suggesting that global banks increase (decrease) the share of their lending to foreign borrowers when they facing higher uncertainty in a local country. Note that an increase in the share does not mean that global banks increase the amount of cross-border lending. Although global banks reduce cross-border lending in response to uncertainty shocks - as we have seen in the previous section-, they may reduce local lending in foreign currencies even more, thereby shifting towards cross-border lending effectively. ${ }^{23}$

Table 9 shows the results from estimating equation (4). The sample size is somewhat reduced compared to Table 2 because we have to drop some reporting countries like the U.S. where global banks do not report their local claims. The signs of coefficients on some control variables, such as real GDP growth and the policy rate switch their sign in this analysis, suggesting that behaviors of gross cross-border claims do not necessarily coincide with those of local claims in foreign currencies. For example, an increase in growth in a reporting country reduces the share of cross-border claims, while it increases cross-border claims in an

\footnotetext{
${ }^{22}$ In other words, $s_{i, j, t}$ is the ratio of "Q:S:C:A:TO1:A:5J:A:Country:A:5J:N" to the sum of “Q:S:C:A:TO1:A:5J:A:Country:A:5J:N" and "Q:S:C:A:TO1:F:5J:A:Country:A:5J:R."

${ }^{23}$ Correa et al. (2017) also test a similar rebalancing channel in response to monetary policy tightening by asking whether domestic credit is less sensitive to the monetary policy compared to foreign credit. However, our methodology of computing directly the share of cross-border claims differs from that of Correa et al. (2017). Correa et al. (2017) interact the policy rate with a dummy variable that takes the value one for observations where the dependent variable measures domestic lending and zero for foreign lending.
} 
absolute term. Global banks expand their lending to both domestic and foreign borrowers during economic expansions and monetary policy tightening in a home country, but they lend more to domestic borrowers. This is likely to be due to the fact that the relative profitability of investment made by domestic firms improves during expansions compared to their foreign counterparts. $^{24}$

Interestingly, the uncertainty variable switches its sign as well, implying that global banks switch the composition of their lending toward foreign borrowers when uncertainty regarding the local economy increases, suggesting the existence of a rebalancing mechanism of global banks in response to uncertainty shocks. We also examine whether this rebalancing mechanism becomes stronger since the GFC. Similar to Table 6, we report the results from a sub-sample analysis in Table 9. We find that the rebalancing channel of global banks indeed becomes more economically and statistically significant since the GFC. Table A.4 in the appendix shows that these results still hold when we use the idiosyncratic uncertainty measure instead.

\section{Instrumental variable approach}

Our analysis could still be subject to endogeneity since unobserved factors might drive uncertainty and macroeconomic conditions in a home country simultaneously. While controlling for GDP growth and stock market growth in a reporting country somewhat mitigates this concern, ${ }^{25}$ we address this concern using an IV approach in the same spirit of Baker and Bloom (2013). To obtain the causal impact of uncertainty shocks on GDP growth,

\footnotetext{
${ }^{24}$ The negative sign on domestic policy rate may seem counterintuitive since it contradicts to the conventional bank lending channel of monetary policy. However, one should note that our focus is on the global banks engaging in cross-border lending and borrowing. To the extent that these global banks tap U.S. dollar money market funds in financial centers to finance their lending activity (Bruno and Shin, 2015), tighter monetary policy in a local economy implies a higher lending rate not necessarily with an increase in funding costs. Global banks can benefit from such a high-interest rate environment in a local economy by lending relatively more to local borrowers.

${ }^{25}$ However, a decline in economic activity associated with heightened uncertainty and the synchronization in business cycles across the world should bias our estimates downward in any case.
} 
Baker and Bloom (2013) use natural disasters, terrorist attacks, and political shocks as an instrument, which are typically exogenous at least in the short-run. ${ }^{26}$

Specifically, we use the disaster shock data-extreme weather and geological events as defined by the Center for Research on the Epidemiology of Disasters (CRED) - as instruments. ${ }^{27}$ These instruments are also scaled by the increase in media mentions of the country in the 15-days after the shock compared to the 15-days before the shock. We proceed with a two-stage least squares (2SLS) approach. In the first step, we regress our measures of uncertainty on the instruments. The results of the first stage in Table 10 confirm that this instrument can be considered as "strong instruments" - that is, the Cragg-Donald Wald Fstatistics are far above the Stock and Yogo (2005) critical values for weak instruments in all cases. Hansen's J statistics for valid instruments are not reported since the equation is exactly identified (we only have one instrument variable).

In the second step, we re-estimate equation (4) using the exogenous part of stock market volatility driven by the instrument- that is, the fitted value of the first step. While the results reported in Table 10 confirm our OLS results in Table 8, the size of the coefficient on uncertainty increases substantially, implying that the OLS estimates are biased downwards. Table A.5 in the appendix confirms that the results from an IV approach still hold when using alternative measures of uncertainty.

\section{Safe vs. risky borrowers}

If the higher uncertainty in a local economy encourages global banks to switch their lending toward relatively safer foreign borrowers, we expect that this mechanism could be weaker when banks lend to borrowers who are genuinely conceived risky. In other words, despite higher uncertainty, global banks may be reluctant to lend to borrowers in a risky

\footnotetext{
${ }^{26}$ To sort out major exogenous events, Baker and Bloom include a shock only if it fulfills at least one of the following conditions: 1 . More than $.001 \%$ of a country's population dead. 2 . More than $.01 \%$ of a country's GDP in damage 3. A successful coup or regime change.

${ }^{27}$ While Baker and Bloom (2013) include other events such as Coup d'état, a revolutionary war or violent uprising as an instrument of uncertainty, our sample of advanced economies rarely contains these events during the last two decades. Thus, we include only the natural disasters in our instrument. See Baker and Bloom (2013) for details on the constructions of these instruments and on the tests regarding the exogeneity of these measures.
} 
economy, regardless of its economic conditions ("flight-to-quality). To test this hypothesis, we interact our main independent variable of uncertainty with the income-level status of counterparty countries. In other words, we interact $U N C_{i, t-1}$ with a dummy variable $E M_{j}$ taking a value of one if a counterparty country $j$ is an emerging market economy and zero otherwise.

$$
s_{i, j, t}=\alpha_{j, t}+\beta X_{i, t-1}+\gamma U N C_{i, t-1}+\delta E M_{j} U N C_{i, t-1}+\varepsilon_{i, j, t}
$$

Table 11 shows that the interaction term is indeed negative and statistically significant, suggesting that while global banks switch their lending toward relatively safer foreign borrowers when they face higher uncertainty in a local economy, this rebalancing occurs only lending towards advanced economies, not emerging market economies. This finding is consistent with the flight-to-quality behavior observed during the episodes of heightened uncertainty, such as the Asian Financial Crisis, 9/11, the collapse of Lehman Brothers, and Taper Tantrum (Beber et al., 2008; Caballero and Krishnamurthy, 2008; De Bock and Filho, 2015) and the existence of the international credit channel of uncertainty shocks suggested in the recent literature to explain much larger effects of uncertainty shocks in emerging markets than in advanced economies (Carrière-Swallow and Céspedes, 2013; Choi, forthcoming).

\section{Conclusion}

This paper contributes to the growing literature on uncertainty and international capital flows. Unlike most prior studies focusing on uncertainty as a global push factor of international capital flows, we use the dyadic structure of the BIS LBS data to effectively control for any shocks affecting economic conditions in recipent countries, and thereby to better identify the role of country-specific uncertainty shocks as both a push and pull factor of cross-border banking flows.

The results suggest that higher uncertainty—measured by country-specific stock market volatility - in a local economy reduces cross-border banking flows from/into this economy. To further shed light on the behaviors of global banks in response to uncertainty shocks, we also study the rebalancing channel of global banks between local and cross- 
border lending. Global banks switch the composition of their lending toward foreign borrowers when uncertainty regarding the local economy increases. Interestingly, this rebalancing occurs only on lending towards advanced economies, not emerging market economies, suggesting the flight-to-quality behavior of the global banks. Our findings are robust to using alternative measures of uncertainty, such as economic policy uncertainty and idiosyncratic stock market volatility purged by the VIX, instrumenting uncertainty using exogenous events, and various sample split exercises. 


\section{References}

Ahmed, Shaghil, and Andrei Zlate. "Capital flows to emerging market economies: A brave new world?.” Journal of International Money and Finance 48 (2014): 221-248.

Avdjiev, Stefan, and Elod Takáts. "Cross-border bank lending during the taper tantrum: the role of emerging market fundamentals.” BIS Quarterly Review (2014).

Avdjiev, Stefan, Bryan Hardy, Sebnem Kalemli-Ozcan, and Luis Servén. “Gross capital inflows to banks, corporates and sovereigns." No. w23116. National Bureau of Economic Research, 2017.

Bachmann, Rüdiger, Steffen Elstner, and Eric R. Sims. "Uncertainty and economic activity: Evidence from business survey data.” American Economic Journal: Macroeconomics 5.2 (2013): 217-249.

Bank of International Settlement. "BIS Quarterly Review.” 2017

Baker, Scott R., Nicholas Bloom, and Steven J. Davis. "Measuring economic policy uncertainty." Quarterly Journal of Economics 131.4 (2016): 1593-1636.

Baum, Christopher F., Mustafa Caglayan, and Neslihan Ozkan. "The impact of macroeconomic uncertainty on bank lending behavior.” Working Paper 2002.

Beber, Alessandro, Michael W. Brandt, and Kenneth A. Kavajecz. "Flight-to-quality or flight-to-liquidity? Evidence from the euro-area bond market." Review of Financial Studies 22.3 (2008): 925-957.

Bekaert, Geert, Marie Hoerova, and Marco Lo Duca. "Risk, uncertainty and monetary policy.” Journal of Monetary Economics 60.7 (2013): 771-788.

Bernal, Oscar, Jean-Yves Gnabo, and Grégory Guilmin. "Economic policy uncertainty and risk spillovers in the Eurozone.” Journal of International Money and Finance 65 (2016): 2445.

Bernanke, Ben. "Irreversibility, uncertainty, and cyclical investment." Quarterly Journal of Economics, Vol. 97, No. 1, (1983), pp. 85-106.

Bloom, Nicholas. "The impact of uncertainty shocks.” Econometrica 77.3 (2009): 623-685.

Bloom, Nicholas. “Observations on uncertainty.” Australian Economic Review 50.1 (2017): 79-84. 
Bordo, Michael D., John V. Duca, and Christoffer Koch. "Economic policy uncertainty and the credit channel: Aggregate and bank level US evidence over several decades." Journal of Financial Stability 26 (2016): 90-106.

Broner, Fernando, Tatiana Didier, Aitor Erce, and Sergio L. Schmukler. "Gross capital flows: Dynamics and crises.” Journal of Monetary Economics 60, no. 1 (2013): 113-133.

Bruno, Valentina, and Hyun Song Shin. "Cross-border banking and global liquidity." Review of Economic Studies 82.2 (2014): 535-564.

Bruno, Valentina, and Hyun Song Shin. "Capital flows and the risk-taking channel of monetary policy.” Journal of Monetary Economics 71 (2015): 119-132.

Caballero, Ricardo J., and Arvind Krishnamurthy. "Collective risk management in a flight to quality episode.” Journal of Finance 63.5 (2008): 2195-2230.

Calvo, Guillermo A., Leonardo Leiderman, and Carmen M. Reinhart. "Inflows of Capital to Developing Countries in the 1990s.” Journal of Economic Perspectives 10.2 (1996): 123-139.

Carrière-Swallow, Yan, and Luis Felipe Céspedes. "The impact of uncertainty shocks in emerging market economies.” Journal of International Economics 90.2 (2013): 316-325.

Cerutti, Eugenio, Stijn Claessens, and Damien Puy. "Push factors and capital flows to emerging markets: why knowing your lender matters more than fundamentals." No. 15-127. International Monetary Fund, (2015a).

Cerutti, Eugenio, Galina Hale, and Camelia Minoiu. "Financial crises and the composition of cross-border lending." Journal of International Money and Finance 52 (2015b): 60-81.

Cerutti, Eugenio, Stijn Claessens, and Lev Ratnovski. "Global liquidity and cross-border bank flows.” Economic Policy 32.89 (2017): 81-125.

Cetorelli, Nicola, and Linda S. Goldberg. "Global banks and international shock transmission: Evidence from the crisis.” IMF Economic Review 59.1 (2011): 41-76.

Choi, Sangyup. "The impact of US financial uncertainty shocks on emerging market economies: An international credit channel." Open Economies Review (forthcoming). doi:10.1007/s11079-017-9471-y

Choi, Sangyup. "Variability in the effects of uncertainty shocks: New stylized facts from OECD countries.” Journal of Macroeconomics 53 (2017): 127-144.

Choi, Sangyup, Davide Furceri, Yi Huang, and Prakash Loungani. "Aggregate uncertainty and sectoral productivity growth: The role of credit constraints." Journal of International Money and Finance (forthcoming). doi:10.1016/j.jimonfin.2017.07.016 
Christiano, Lawrence J., Roberto Motto, and Massimo Rostagno. "Risk shocks." American Economic Review 104.1 (2014): 27-65.

Correa, Ricardo, Teodora Paligorova, Horacio Sapriza, and Andrei Zlate. "Cross-Border Bank Flows and Monetary Policy.” Working Paper 2017

De Bock, Reinout, and Irineu de Carvalho Filho. "The behavior of currencies during risk-off episodes.” Journal of International Money and Finance 53 (2015): 218-234.

Fogli, Alessandra, and Fabrizio Perri. "Macroeconomic volatility and external imbalances." Journal of Monetary Economics 69 (2015): 1-15.

Forbes, Kristin J., and Francis E. Warnock. "Capital flow waves: Surges, stops, flight, and retrenchment.” Journal of International Economics 88.2 (2012): 235-251.

Fratzscher, Marcel. "Capital flows, push versus pull factors and the global financial crisis." Journal of International Economics 88.2 (2012): 341-356.

Fratzscher, Marcel, Marco Lo Duca, and Roland Straub. "On the international spillovers of US quantitative easing." Economic Journal (2016).

Gauvin, Ludovic, Cameron McLoughlin, and Dennis Reinhardt. "Policy uncertainty spillovers to emerging markets-evidence from capital flows.” Working paper (2014).

Ghosh, Atish R., Mahvash S. Qureshi, Jun Il Kim, and Juan Zalduendo. "Surges.” Journal of International Economics 2, no. 92 (2014): 266-285.

Gourinchas, Pierre-Olivier, and Helene Rey. "International financial adjustment.” Journal of Political Economy 115.4 (2007): 665-703.

Gourio, Francois, Michael Siemer, and Adrien Verdelhan. "Uncertainty and international capital flows." Working paper (2015).

Ivashina, Victoria, David S. Scharfstein, and Jeremy C. Stein. "Dollar funding and the lending behavior of global banks.” Quarterly Journal of Economics 130.3 (2015): 1241-1281.

Julio, Brandon, and Youngsuk Yook. "Policy uncertainty, irreversibility, and cross-border flows of capital.” Journal of International Economics 103 (2016): 13-26.

Kalemli-Ozcan, Sebnem, Elias Papaioannou, and Jose-Luis Peydro. "Financial regulation, financial globalization, and the synchronization of economic activity." Journal of Finance 68.3 (2013): 1179-1228. 
Kaminsky, Graciela L., Carmen M. Reinhart, and Carlos A. Végh. "When it rains, it pours: procyclical capital flows and macroeconomic policies." NBER macroeconomics annual 19 (2004): 11-53.

Khwaja, Asim Ijaz, and Atif Mian. "Tracing the impact of bank liquidity shocks: Evidence from an emerging market.” American Economic Review 98.4 (2008): 1413-1442.

Kim, Woochan, and Shang-Jin Wei. "Foreign portfolio investors before and during a crisis." Journal of International Economics 56.1 (2002): 77-96.

Kleimeier, Stefanie, Harald Sander, and Sylvia Heuchemer. "Financial crises and crossborder banking: New evidence." Journal of International Money and Finance 32 (2013): 884915.

Lane, Philip R., and Gian Maria Milesi-Ferretti. "The external wealth of nations mark II: Revised and extended estimates of foreign assets and liabilities, 1970-2004." Journal of International Economics 73.2 (2007): 223-250.

Milesi-Ferretti, Gian-Maria, and Cédric Tille. "The great retrenchment: international capital flows during the global financial crisis.” Economic Policy 26.66 (2011): 289-346.

Minoiu, Camelia, and Javier A. Reyes. "A network analysis of global banking: 1978-2010." Journal of Financial Stability 9.2 (2013): 168-184.

Morikawa, Masayuki. "Business uncertainty and investment: Evidence from Japanese companies." Journal of Macroeconomics 49 (2016): 224-236.

Obstfeld, Maurice. "Financial flows, financial crises, and global imbalances." Journal of International Money and Finance 31.3 (2012): 469-480.

Ozturk, Ezgi, and Xuguang Simon Sheng. "Measuring global and country-specific uncertainty." Journal of International Money and Finance (forthcoming).

Passari, Evgenia, and Hélène Rey. "Financial flows and the international monetary system." Economic Journal 125.584 (2015): 675-698.

Raddatz, Claudio, and Sergio L. Schmukler. "On the international transmission of shocks: Micro-evidence from mutual fund portfolios." Journal of International Economics 88.2 (2012): 357-374.

Raunig, Burkhard, Johann Scharler, and Friedrich Sindermann. "Do banks lend less in uncertain times?" Economica (2016).

Rey, Hélène. "Dilemma not trilemma: the global financial cycle and monetary policy independence." National Bureau of Economic Research, 2015. 
Shin, Hyun Song. "Global banking glut and loan risk premium.” IMF Economic Review 60.2 (2012): 155-192.

Stock, James H., and Motohiro Yogo. "Testing for Weak Instruments in Linear IV Regression." Identification and Inference for Econometric Models: Essays in Honor of Thomas Rothenberg (2005) 


\section{Figures and Tables}

Figure 1. Total cross-border bank claims and liabilities

a) U.S.
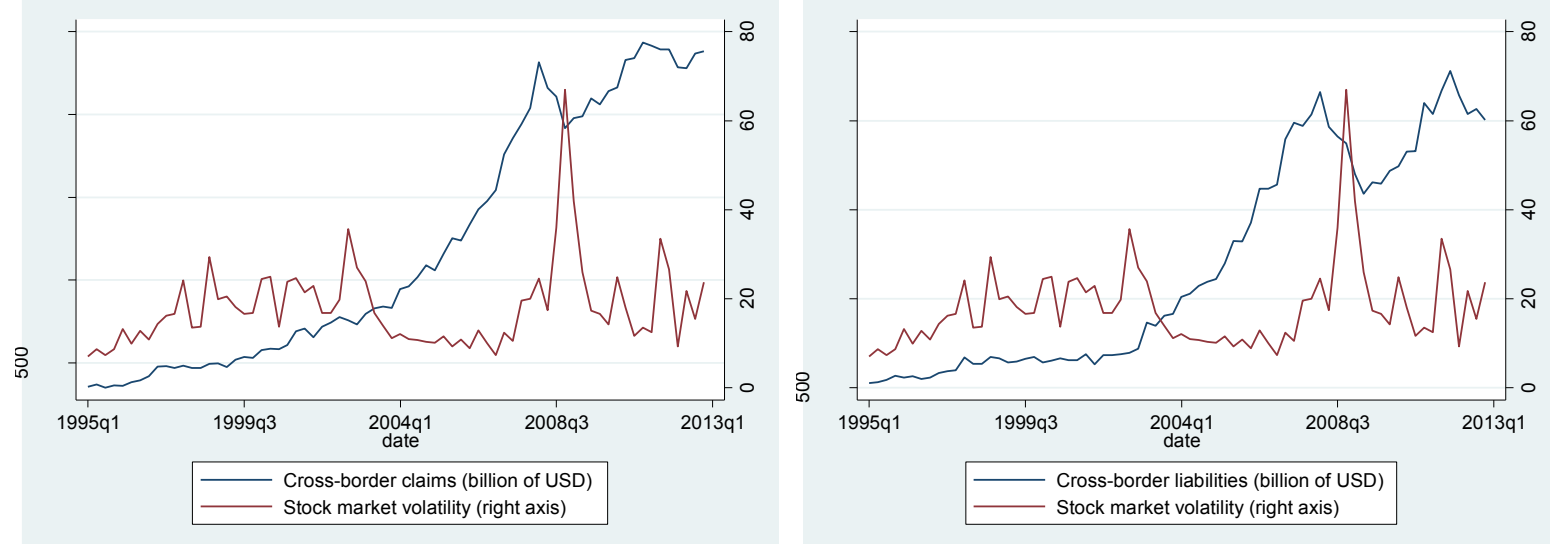

\section{b) Germany}
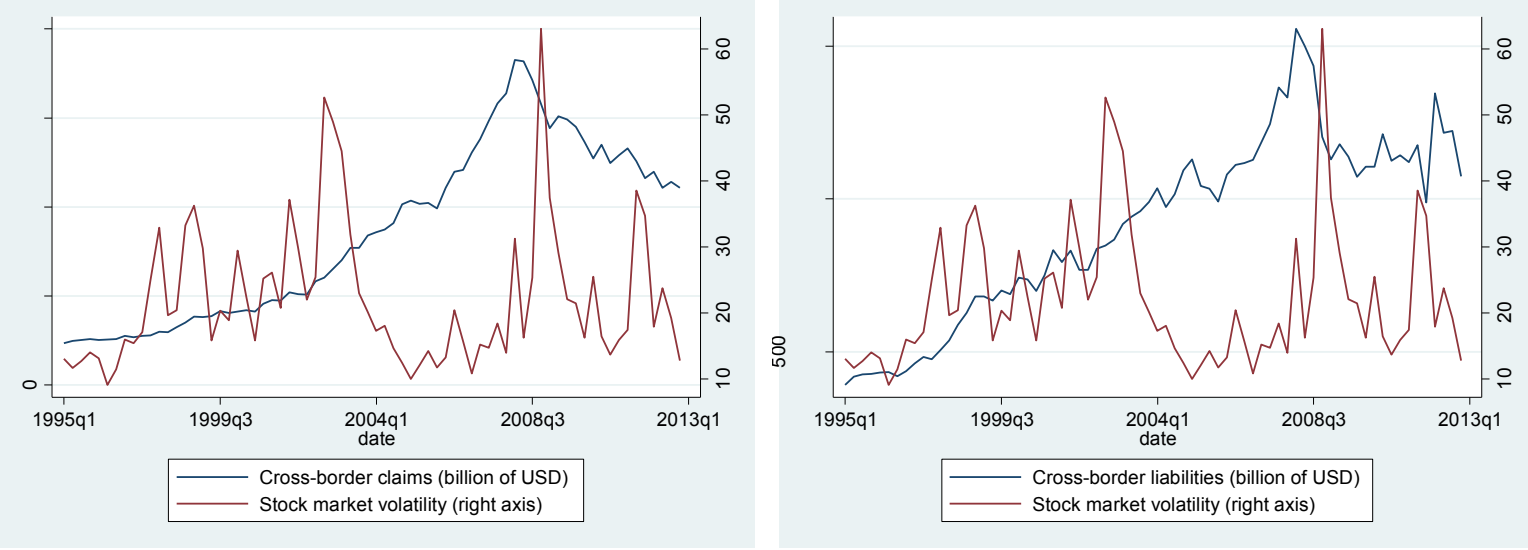

\section{c) Brazil}
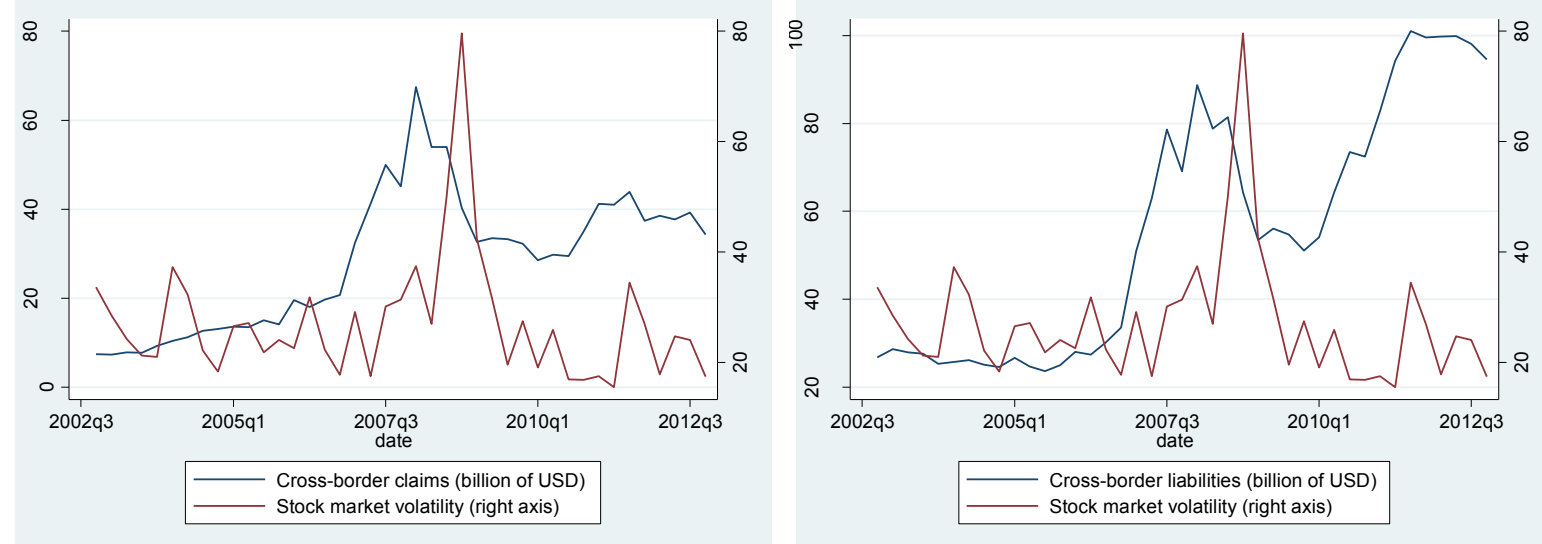

Note: Uncertainty is measured by stock market volatility in a reporter (source) country. 
Figure 2. Examples of the bilateral cross-border bank claims and liabilities: a reportercounterparty pair

\section{a) U.S.-Germany}
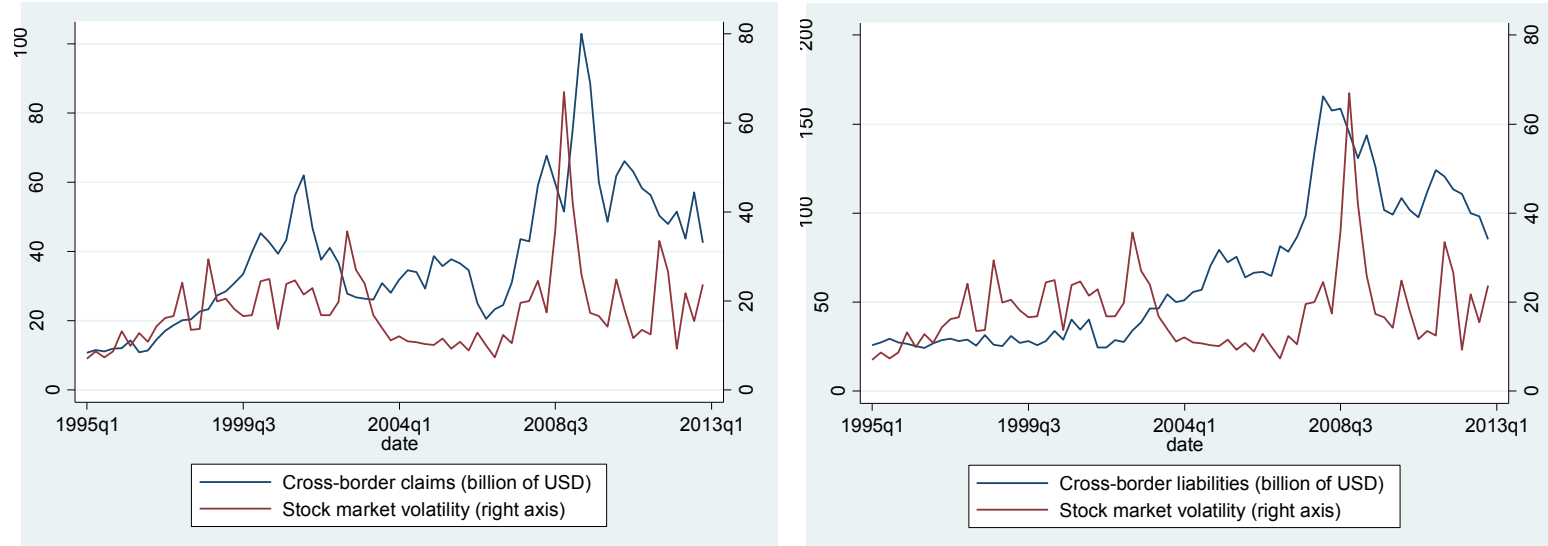

b) U.S. -Brazil
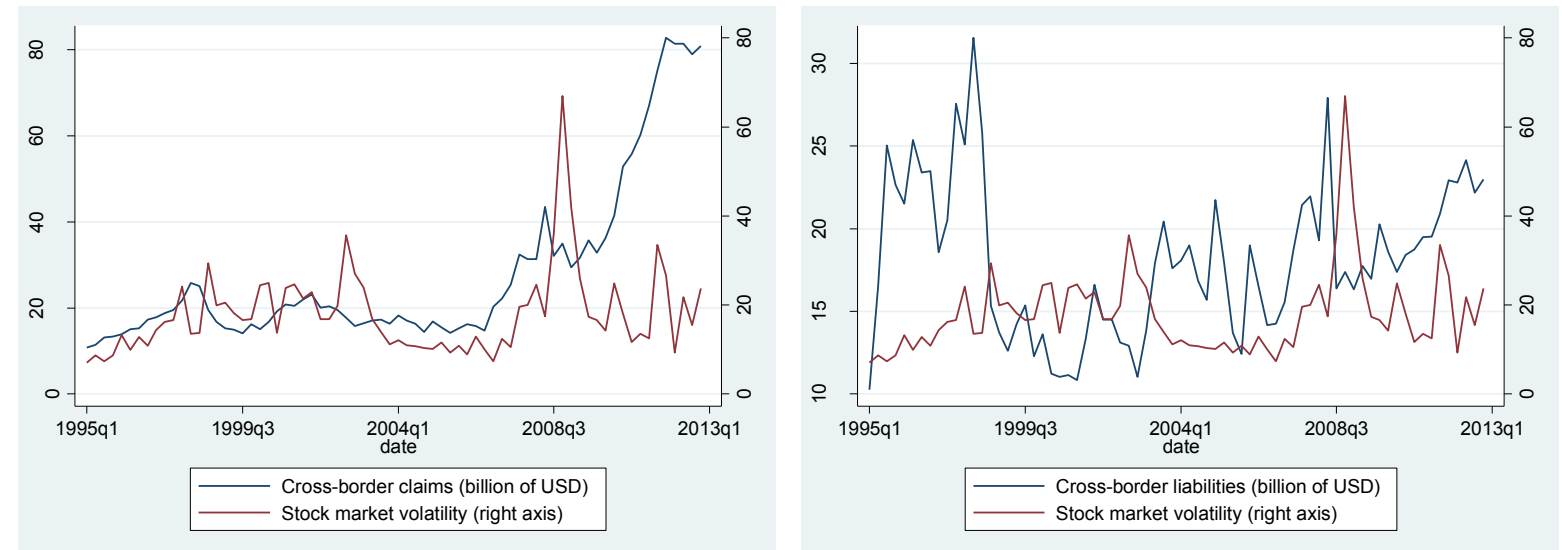

\section{c) Germany-Brazil}
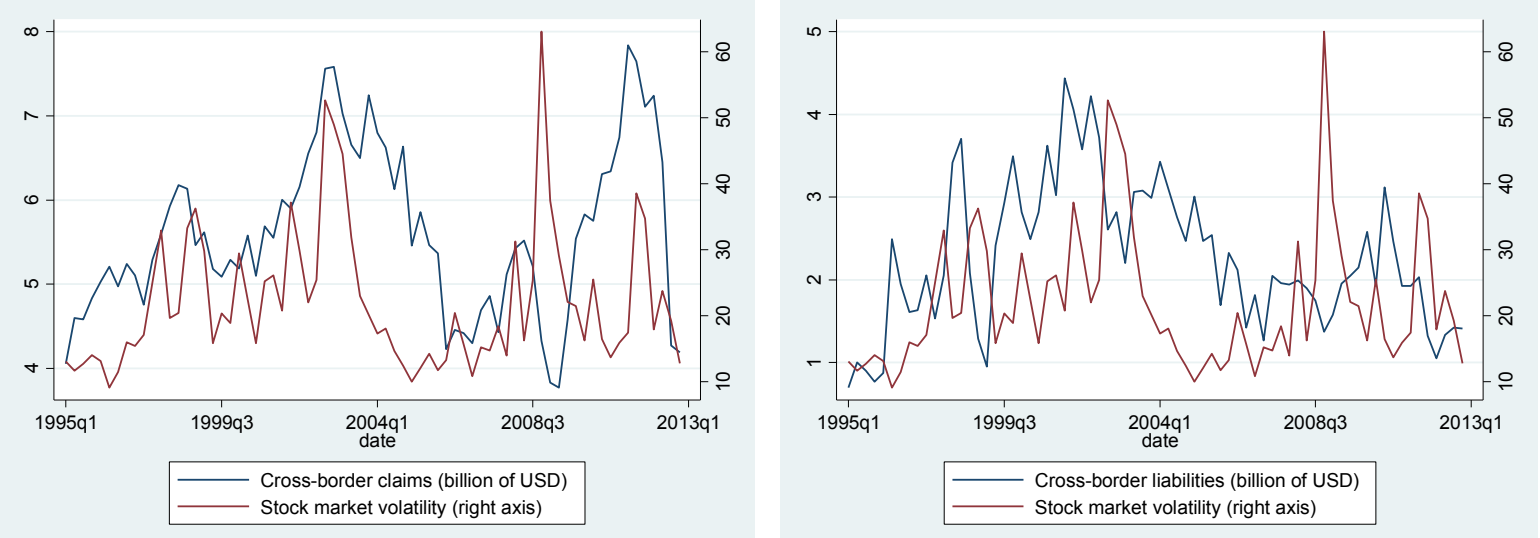

Note: Uncertainty is measured by stock market volatility in a reporter (source) country. 
Table 1. Summary statistics

\begin{tabular}{lcccc}
\hline Variable & Obs. & Mean & Median & $\begin{array}{c}\text { Standard } \\
\text { deviation }\end{array}$ \\
\hline Growth of cross-border claims (q-o-q) & 30,608 & 3.136 & 1.225 & 40.751 \\
Growth of cross-border liabilities (q-o-q) & 29,889 & 2.998 & 1.359 & 50.930 \\
Stock market volatility & 30,608 & 19.943 & 17.211 & 10.238 \\
Economic policy uncertainty & 24,901 & 105.921 & 97.412 & 44.417 \\
Real GDP growth (q-o-q) & 30,608 & 0.600 & 0.645 & 1.059 \\
Growth of stock market (q-o-q) & 30,608 & 1.254 & 2.214 & 9.826 \\
Inflation rate (q-o-q) & 30,608 & 0.609 & 0.573 & 0.626 \\
Policy rate & 30,608 & 3.666 & 3.370 & 2.653 \\
Growth of nominal exchange rate (q-o-q) & 30,608 & -0.127 & 0.000 & 4.243 \\
Growth of private credit (q-o-q) & 17,973 & 1.506 & 1.372 & 2.143 \\
External debt to GDP ratio & 19,605 & 80.704 & 74.052 & 53.674 \\
\hline
\end{tabular}

Note: Growth rates are calculated quarter-over-quarter. All variables are in percentage points. 
Table 2. Baseline analysis

\begin{tabular}{|c|c|c|c|c|c|c|}
\hline \multirow[b]{2}{*}{ Explanatory variables } & \multicolumn{3}{|c|}{ Growth of claims (outflows) } & \multicolumn{3}{|c|}{ Growth of liabilities (inflows) } \\
\hline & (I) & (II) & (III) & (IV) & (V) & (VI) \\
\hline \multirow[t]{2}{*}{ Log of uncertainty } & $-1.670 * *$ & $-2.845^{* *}$ & $-2.716 * *$ & $-2.369 * *$ & $-2.734 * *$ & $-2.302 *$ \\
\hline & $(0.824)$ & $(1.150)$ & $(1.211)$ & $(0.957)$ & $(1.328)$ & $(1.289)$ \\
\hline \multirow[t]{2}{*}{ Real GDP growth } & $0.852 * * *$ & $0.782 * *$ & 0.391 & $0.856^{* *}$ & 0.207 & -0.598 \\
\hline & $(0.290)$ & $(0.402)$ & $(0.422)$ & $(0.393)$ & $(0.629)$ & $(0.604)$ \\
\hline \multirow[t]{2}{*}{ Stock market growth } & 0.002 & $-0.067 *$ & -0.062 & -0.017 & 0.063 & 0.029 \\
\hline & $(0.031)$ & $(0.039)$ & $(0.040)$ & $(0.041)$ & $(0.070)$ & $(0.065)$ \\
\hline \multirow[t]{2}{*}{ CPI inflation } & -0.349 & -1.331 & -0.995 & 0.782 & 0.587 & 0.477 \\
\hline & $(0.508)$ & $(0.879)$ & $(0.922)$ & $(0.615)$ & $(1.27)$ & $(1.017)$ \\
\hline \multirow[t]{2}{*}{ Policy rate } & $0.557 * * *$ & $0.718 * * *$ & $0.669 * * *$ & 0.147 & 0.244 & 0.062 \\
\hline & $(0.107)$ & $(0.136)$ & $(0.133)$ & $(0.114)$ & $(0.166)$ & $(0.150)$ \\
\hline \multirow[t]{2}{*}{ Nominal exchange rate growth } & -0.094 & -0.123 & $-0.153 *$ & 0.003 & -0.093 & $-0.217 * *$ \\
\hline & $(0.078)$ & $(0.088)$ & $(0.089)$ & $(0.11)$ & $(0.138)$ & $(0.109)$ \\
\hline \multirow[t]{2}{*}{ Private credit growth } & & 0.109 & 0.029 & & 0.035 & 0.035 \\
\hline & & $(0.183)$ & $(0.194)$ & & $(0.211)$ & $(0.200)$ \\
\hline \multirow[t]{2}{*}{ External debt to GDP } & & & $-0.022 * * *$ & & & $-0.018 * * *$ \\
\hline & & & $(0.004)$ & & & $(0.006)$ \\
\hline Obs & 30,608 & 17,462 & 16,431 & 29,889 & 16,725 & 15,416 \\
\hline R-squared & 0.13 & 0.14 & 0.15 & 0.14 & 0.15 & 0.16 \\
\hline
\end{tabular}

Note: The dependent variables are the growth rate of exchange rate-adjusted cross-border claims in column (I) to (III) and the growth rate of exchange rateadjusted cross-border liabilities in column (IV) to (VI). All independent variables are lagged by one period. Heteroskedasticity-robust standard errors in parentheses. Standard errors are clustered at the reporting-counterparty country levels. *** denotes $1 \%$ significant level, ** denotes $5 \%$ significance level, and $*$ denotes $10 \%$ significance level. 
Table 3. Link to the previous studies: Emerging market economies only

\begin{tabular}{|c|c|c|c|c|c|c|}
\hline \multirow[b]{2}{*}{ Explanatory variables } & \multicolumn{3}{|c|}{ Reporter: emerging market economies only } & \multicolumn{3}{|c|}{ Counterparty: emerging market economies only } \\
\hline & (I) & (II) & (III) & (IV) & $(\mathrm{V})$ & (VI) \\
\hline \multirow[t]{2}{*}{ Log of uncertainty } & $-8.126^{*}$ & $-14.287^{*}$ & $-16.928 * *$ & $-2.177^{*}$ & $-3.695^{* *}$ & $-4.016^{* *}$ \\
\hline & $(4.114)$ & $(7.727)$ & $(7.821)$ & $(1.223)$ & $(1.792)$ & $(1.797)$ \\
\hline \multirow[t]{2}{*}{ Real GDP growth } & 1.588 & -1.234 & -1.381 & $1.512 * * *$ & $1.667 * * *$ & $1.073 *$ \\
\hline & $(1.241)$ & $(1.666)$ & $(1.745)$ & $(0.448)$ & $(0.550)$ & $(0.561)$ \\
\hline \multirow[t]{2}{*}{ Stock market growth } & $0.296 * *$ & 0.138 & 0.097 & -0.028 & $-0.137 * *$ & $-0.126^{* *}$ \\
\hline & $(0.114)$ & $(0.472)$ & $(0.491)$ & $(0.043)$ & $(0.053)$ & $(0.053)$ \\
\hline \multirow[t]{2}{*}{ CPI inflation } & 1.046 & -2.872 & 0.711 & $-1.462 *$ & $-3.397 * * *$ & $-2.517 * *$ \\
\hline & $(1.257)$ & $(2.309)$ & (3.019) & $(0.764)$ & $(1.246)$ & $(1.253)$ \\
\hline \multirow[t]{2}{*}{ Policy rate } & $0.726 * *$ & $1.429 * *$ & $1.648 * *$ & $0.920 * * *$ & $1.371 * * *$ & $1.188 * * *$ \\
\hline & $(0.327)$ & $(0.626)$ & $(0.698)$ & $(0.215)$ & $(0.31)$ & $(0.304)$ \\
\hline \multirow[t]{2}{*}{ Nominal exchange rate growth } & 0.273 & $0.101)$ & 0.189 & 0.095 & $0.148)$ & 0.133 \\
\hline & $(0.194)$ & $(0.287$ & $(0.293)$ & $(0.113)$ & $(0.133)$ & $(0.122)$ \\
\hline \multirow[t]{2}{*}{ Private credit growth } & & 0.687 & 0.753 & & 0.297 & 0.132 \\
\hline & & $(0.651)$ & $(0.794)$ & & $(0.273)$ & $(0.278)$ \\
\hline \multirow[t]{2}{*}{ External debt to GDP } & & & 0.054 & & & $-0.029 * * *$ \\
\hline & & & $(0.128)$ & & & $(0.007)$ \\
\hline Obs & 2,671 & 1,400 & 1,358 & 13,685 & 7,694 & 7,249 \\
\hline R-squared & 0.37 & 0.41 & 0.42 & 0.15 & 0.17 & 0.18 \\
\hline
\end{tabular}

Note: The dependent variables are the growth rate of exchange rate-adjusted cross-border claims. All independent variables are lagged by one period.

Heteroskedasticity-robust standard errors are clustered at the reporting-counterparty country levels. *** denotes $1 \%$ significant level, $* *$ denotes $5 \%$ significance level, and * denotes $10 \%$ significance level. 
Table 4. Robustness check: Alternative measure of uncertainty (economic policy uncertainty)

\begin{tabular}{|c|c|c|c|c|c|c|}
\hline \multirow[b]{2}{*}{ Explanatory variables } & \multicolumn{3}{|c|}{ Growth of claims (outflows) } & \multicolumn{3}{|c|}{ Growth of liabilities (inflows) } \\
\hline & (I) & (II) & (III) & (IV) & (V) & $(\mathrm{VI})$ \\
\hline \multirow[t]{2}{*}{ Log of uncertainty } & $-1.923 * *$ & $-2.664 * *$ & $-3.574 * * *$ & $-2.621 * *$ & $-3.654 * *$ & $-2.832 *$ \\
\hline & $(0.930)$ & $(1.211)$ & $(1.239)$ & $(1.207)$ & $(1.720)$ & $(1.681)$ \\
\hline \multirow[t]{2}{*}{ Real GDP growth } & $1.446 * * *$ & $1.330 * * *$ & $0.920 * *$ & $0.888 *$ & 0.832 & -0.052 \\
\hline & $(0.380)$ & $(0.406)$ & $(0.430)$ & $(0.468)$ & $(0.659)$ & $(0.705)$ \\
\hline \multirow[t]{2}{*}{ Stock market growth } & 0.049 & -0.045 & -0.056 & 0.035 & 0.079 & 0.080 \\
\hline & $(0.037)$ & $(0.042)$ & $(0.042)$ & $(0.051)$ & $(0.073)$ & $(0.074)$ \\
\hline \multirow[t]{2}{*}{ CPI inflation } & -0.492 & -1.317 & -0.807 & 0.121 & -0.852 & 0.436 \\
\hline & $(0.587)$ & $(0.944)$ & $(1.005)$ & $(0.608)$ & $(1.155)$ & $(1.233)$ \\
\hline \multirow[t]{2}{*}{ Policy rate } & $0.479 * * *$ & $0.587 * * *$ & $0.540 * * *$ & $0.212 *$ & $0.263 *$ & 0.167 \\
\hline & $(0.114)$ & $(0.128)$ & $(0.140)$ & $(0.120)$ & $(0.141)$ & $(0.145)$ \\
\hline \multirow[t]{2}{*}{ Nominal exchange rate growth } & -0.034 & -0.085 & -0.085 & 0.123 & 0.036 & 0.027 \\
\hline & $(0.084)$ & $(0.090)$ & $(0.090)$ & $(0.116)$ & $(0.134)$ & $(0.134)$ \\
\hline \multirow[t]{2}{*}{ Private credit growth } & & 0.099 & -0.031 & & 0.113 & -0.060 \\
\hline & & $(0.181)$ & $(0.193)$ & & $(0.219)$ & $(0.227)$ \\
\hline \multirow[t]{2}{*}{ External debt to GDP } & & & $-0.022 * * *$ & & & $-0.028 * * *$ \\
\hline & & & $(0.005)$ & & & $(0.007)$ \\
\hline Obs & 21,564 & 14,623 & 13,715 & 21,212 & 14,009 & 13,369 \\
\hline R-squared & 0.15 & 0.16 & 0.17 & 0.17 & 0.17 & 0.18 \\
\hline
\end{tabular}

Note: The dependent variables are the growth rate of exchange rate-adjusted cross-border claims in column (I) to (III) and the growth rate of exchange rateadjusted cross-border liabilities in column (IV) to (VI). Heteroskedasticity-robust standard errors are clustered at the reporting-counterparty country levels. *** denotes $1 \%$ significant level, ** denotes $5 \%$ significance level, and * denotes $10 \%$ significance level. 
Table 5. Robustness check: Alternative measure of uncertainty (idiosyncratic stock market volatility)

\begin{tabular}{|c|c|c|c|c|c|c|}
\hline \multirow[b]{2}{*}{ Explanatory variables } & \multicolumn{3}{|c|}{ Growth of claims (outflows) } & \multicolumn{3}{|c|}{ Growth of liabilities (inflows) } \\
\hline & (I) & (II) & (III) & (IV) & $(\mathrm{V})$ & (VI) \\
\hline \multirow[t]{2}{*}{ Log of uncertainty } & $-0.069 *$ & $-0.119 * *$ & $-0.125 * *$ & $-0.100 * *$ & $-0.117^{*}$ & $-0.106^{*}$ \\
\hline & $(0.039)$ & $(0.050)$ & $(0.055)$ & $(0.047)$ & $(0.068)$ & $(0.062)$ \\
\hline \multirow[t]{2}{*}{ Real GDP growth } & $0.853 * * *$ & $0.782^{*}$ & 0.446 & $0.859 * *$ & 0.207 & -0.670 \\
\hline & $(0.290)$ & $(0.404)$ & $(0.430)$ & $(0.393)$ & $(0.633)$ & $(0.604)$ \\
\hline \multirow[t]{2}{*}{ Stock market growth } & 0.002 & $-0.071 *$ & $-0.065^{*}$ & -0.018 & 0.058 & 0.027 \\
\hline & $(0.032)$ & $(0.039)$ & $(0.040)$ & $(0.041)$ & $(0.070)$ & $(0.065)$ \\
\hline \multirow[t]{2}{*}{ CPI inflation } & -0.333 & -1.312 & -0.782 & 0.804 & 0.599 & 0.496 \\
\hline & $(0.508)$ & $(0.882)$ & $(0.939)$ & $(0.616)$ & $(1.265)$ & $(1.008)$ \\
\hline \multirow[t]{2}{*}{ Policy rate } & $0.543 * * *$ & $0.703 * * *$ & $0.597 * * *$ & 0.128 & 0.230 & 0.037 \\
\hline & $(0.106)$ & $(0.135)$ & $(0.149)$ & $(0.112)$ & $(0.162)$ & $(0.144)$ \\
\hline \multirow[t]{2}{*}{ Nominal exchange rate growth } & -0.093 & -0.121 & -0.123 & 0.004 & -0.091 & $-0.193 *$ \\
\hline & $(0.078)$ & $(0.088)$ & $(0.090)$ & $(0.110)$ & $(0.139)$ & $(0.108)$ \\
\hline \multirow[t]{2}{*}{ Private credit growth } & & 0.123 & 0.022 & & 0.049 & -0.091 \\
\hline & & $(0.183)$ & $(0.194)$ & & $(0.211)$ & $(0.196)$ \\
\hline \multirow[t]{2}{*}{ External debt to GDP } & & & $-0.023 * * *$ & & & $-0.021 * * *$ \\
\hline & & & $(0.005)$ & & & $(0.006)$ \\
\hline Obs & 30,608 & 17,462 & 16,431 & 29,889 & 16,725 & 15,416 \\
\hline R-squared & 0.13 & 0.14 & 0.15 & 0.14 & 0.15 & 0.16 \\
\hline
\end{tabular}

Note: The dependent variables are the growth rate of exchange rate-adjusted cross-border claims in column (I) to (III) and the growth rate of exchange rateadjusted cross-border liabilities in column (IV) to (VI). All independent variables are lagged by one period. Heteroskedasticity-robust standard errors are

clustered at the reporting-counterparty country levels. *** denotes $1 \%$ significant level, ** denotes $5 \%$ significance level, and $*$ denotes $10 \%$ significance level. 
Table 6. Robustness check: Before and after the Global Financial Crisis

\begin{tabular}{|c|c|c|c|c|}
\hline & \multicolumn{2}{|c|}{ Growth of claims (outflows) } & \multicolumn{2}{|c|}{ Growth of liabilities (inflows) } \\
\hline & (I) & (II) & (III) & (IV) \\
\hline & $\begin{array}{c}\text { Before the GFC } \\
(1995 \mathrm{Q} 1-2007 \mathrm{Q} 2)\end{array}$ & $\begin{array}{c}\text { After the GFC } \\
\text { (2007Q3-2012Q4) }\end{array}$ & $\begin{array}{c}\text { Before the GFC } \\
\text { (1995Q1-2007Q2) }\end{array}$ & $\begin{array}{c}\text { After the GFC } \\
(2007 \mathrm{Q} 3-2012 \mathrm{Q} 4)\end{array}$ \\
\hline \multirow[t]{2}{*}{ Log of uncertainty } & $-1.983 * *$ & $-2.841^{* *}$ & $-2.111 * *$ & $-3.550^{*}$ \\
\hline & $(1.026)$ & $(1.289)$ & $(1.052)$ & $(1.910)$ \\
\hline \multirow[t]{2}{*}{ Real GDP growth } & $0.757^{*}$ & $0.909 * * *$ & $0.973^{*}$ & 0.672 \\
\hline & $(0.453)$ & $(0.297)$ & $(0.550)$ & $(0.554)$ \\
\hline \multirow[t]{2}{*}{ Stock market growth } & 0.006 & 0.008 & $-0.169 * * *$ & 0.106 \\
\hline & $(0.048)$ & $(0.033)$ & $(0.060)$ & $(0.065)$ \\
\hline \multirow[t]{2}{*}{ CPI inflation } & -0.878 & -0.183 & 0.778 & 0.916 \\
\hline & $(0.843)$ & $(0.536)$ & $(0.986)$ & $(0.759)$ \\
\hline \multirow[t]{2}{*}{ Policy rate } & $0.691 * * *$ & 0.177 & 0.135 & 0.152 \\
\hline & $(0.143)$ & $(0.179)$ & $(0.124)$ & $(0.222)$ \\
\hline \multirow[t]{2}{*}{$\begin{array}{l}\text { Nominal exchange rate } \\
\text { growth }\end{array}$} & -0.058 & 0.003 & 0.011 & -0.003 \\
\hline & $(0.141)$ & $(0.079)$ & $(0.158)$ & $(0.142)$ \\
\hline Obs & 18,846 & 11,578 & 18,808 & 1,1081 \\
\hline R-squared & 0.143 & 0.119 & 0.16 & 0.13 \\
\hline
\end{tabular}

Note: The dependent variables are the growth rate of exchange rate-adjusted cross-border claims in column (I) to (II) and the growth rate of exchange rate-adjusted cross-border liabilities in column (III) to (IV). All independent variables are lagged by one period. Heteroskedasticity-robust standard errors are clustered at the reportingcounterparty country levels. ${ }^{* *}$ denotes $1 \%$ significant level, $* *$ denotes $5 \%$ significance level, and $*$ denotes $10 \%$ significance level. 
Table 7. Robustness check: Euro area vs. non-euro area countries

\begin{tabular}{lcccc}
\hline & \multicolumn{2}{c}{ Growth of claims (outflows) } & \multicolumn{2}{c}{ Growth of liabilities (inflows) } \\
& Euro area & Non-euro area & Euro area & Non-euro area \\
\cline { 2 - 5 } & $-5.136^{* *}$ & $-2.827^{*}$ & -4.167 & -1.503 \\
\hline Log of uncertainty & $(2.444)$ & $(1.511)$ & $(2.523)$ & $(2.078)$ \\
Real GDP growth & 0.352 & 0.351 & 0.025 & -1.120 \\
& $(0.840)$ & $(0.587)$ & $(1.173)$ & $(0.827)$ \\
Stock market growth & $-0.186^{*}$ & -0.023 & 0.005 & 0.064 \\
& $(0.104)$ & $(0.048)$ & $(0.161)$ & $(0.084)$ \\
CPI inflation & 1.646 & -1.672 & -0.294 & 2.051 \\
& $(1.494)$ & $(1.190)$ & $(2.164)$ & $(1.611)$ \\
Policy rate & & $0.621^{* * *}$ & & -0.151 \\
& & $(0.191)$ & & $(0.219)$ \\
Nominal exchange rate & & 0.003 & & -0.098 \\
growth & & $(0.079)$ & & $(0.160)$ \\
Private credit growth & -0.247 & 0.225 & & 0.029 \\
& $(0.208)$ & $(0.312)$ & & $(0.370)$ \\
External debt to GDP & -0.013 & $-0.033^{* *}$ & & $-0.055^{* * *}$ \\
& $(0.009)$ & $(0.014)$ & 0.32 & $(0.020)$ \\
\hline Obs & 6,559 & 9,508 & & 8,856 \\
R-squared & 0.32 & 0.22 & 0.23 \\
\hline
\end{tabular}

Note: The dependent variables are the growth rate of exchange rate-adjusted cross-border claims in column (I) to (II) and the growth rate of exchange rate-adjusted cross-border liabilities in column (III) to (IV). All independent variables are lagged by one period. Heteroskedasticity-robust standard errors are clustered at the reportingcounterparty country levels. $* * *$ denotes $1 \%$ significant level, $* *$ denotes $5 \%$ significance level, and $*$ denotes $10 \%$ significance level. 
Table 8. Rebalancing between local and cross-border claims

\begin{tabular}{lccc}
\hline & \multicolumn{3}{c}{ Share of cross-border claims } \\
\cline { 2 - 4 } Explanatory variables & (I) & $(\mathrm{II})$ & $(\mathrm{III})$ \\
\hline Log of uncertainty & $0.283^{*}$ & $0.465^{* *}$ & $0.359^{*}$ \\
Real GDP growth & $(0.166)$ & $(0.191)$ & $(0.185)$ \\
& $-0.084^{* * *}$ & $-0.060^{*}$ & -0.012 \\
Stock market growth & $(0.020)$ & $(0.031)$ & $(0.025)$ \\
& -0.002 & -0.002 & -0.001 \\
CPI inflation & $(0.001)$ & $(0.002)$ & $(0.002)$ \\
& -0.062 & $-0.129^{* *}$ & -0.095 \\
Policy rate & $(0.039)$ & $(0.058)$ & $(0.062)$ \\
& $-0.046^{* *}$ & $-0.047^{*}$ & -0.037 \\
Nominal exchange rate growth & $(0.020)$ & $(0.024)$ & $(0.026)$ \\
& $-0.008^{* *}$ & $-0.010^{* *}$ & -0.007 \\
Private credit growth & $(0.004)$ & $(0.005)$ & $(0.005)$ \\
& & -0.025 & 0.003 \\
External debt to GDP & & $(0.019)$ & $(0.019)$ \\
& & & $0.004^{* * *}$ \\
\hline Obs & & & $(0.001)$ \\
R-squared & 24,420 & 14,690 & 14,101 \\
\hline
\end{tabular}

Note: The dependent variables are the ratio of exchange rate-adjusted cross-border claims to the sum of exchange rate-adjusted cross-border claims and local claims in foreign currencies. All independent variables are lagged by one period. Heteroskedasticity-robust standard errors are clustered at the reporting-counterparty country levels. $* * *$ denotes $1 \%$ significant level, $* *$ denotes $5 \%$ significance level, and $*$ denotes $10 \%$ significance level 
Table 9. Rebalancing between local and cross-border claims: Before and after the Global Financial Crisis

\begin{tabular}{|c|c|c|c|c|c|c|}
\hline \multirow{3}{*}{ Explanatory variables } & \multicolumn{6}{|c|}{ Share of cross-border claims } \\
\hline & (I) & (II) & (III) & (IV) & $(\mathrm{V})$ & $(\mathrm{VI})$ \\
\hline & \multicolumn{3}{|c|}{ Before the GFC (1995Q1-2007Q2) } & \multicolumn{3}{|c|}{ After the GFC (2007Q3-2012Q4) } \\
\hline \multirow[t]{2}{*}{ Log of uncertainty } & 0.237 & $0.319 *$ & 0.268 & $0.447 * *$ & $0.571 * *$ & $0.465^{*}$ \\
\hline & $(0.199)$ & $(0.191)$ & $(0.180)$ & $(0.182)$ & $(0.241)$ & $(0.237)$ \\
\hline \multirow[t]{2}{*}{ Real GDP growth } & $-0.093 * * *$ & $-0.095 * *$ & -0.057 & $-0.071 * * *$ & -0.043 & 0.007 \\
\hline & $(0.026)$ & $(0.047)$ & $(0.047)$ & $(0.024)$ & $(0.031)$ & $(0.025)$ \\
\hline \multirow[t]{2}{*}{ Stock market growth } & $0.005 * *$ & $0.008 *$ & 0.004 & $-0.007 * * *$ & $-0.007 * * *$ & $-0.004 *$ \\
\hline & $(0.002)$ & $(0.005)$ & $(0.005)$ & $(0.002)$ & $(0.003)$ & $(0.002)$ \\
\hline \multirow[t]{2}{*}{ CPI inflation } & 0.01 & $-0.230 * * *$ & $-0.229 * *$ & $-0.122 * * *$ & -0.094 & -0.071 \\
\hline & $(0.065)$ & $(0.085)$ & $(0.092)$ & $(0.045)$ & $(0.073)$ & $(0.071)$ \\
\hline \multirow[t]{2}{*}{ Policy rate } & $-0.055^{* *}$ & $-0.041 *$ & -0.028 & -0.039 & -0.058 & -0.043 \\
\hline & $(0.022)$ & $(0.024)$ & $(0.023)$ & $(0.029)$ & $(0.040)$ & $(0.040)$ \\
\hline \multirow[t]{2}{*}{ Nominal exchange rate growth } & $-0.025 * * *$ & $-0.038 * *$ & $-0.032 *$ & -0.001 & -0.002 & -0.002 \\
\hline & $(0.009)$ & $(0.016)$ & $(0.017)$ & $(0.003)$ & $(0.004)$ & $(0.004)$ \\
\hline \multirow[t]{2}{*}{ Private credit growth } & & $-0.048 * *$ & -0.031 & & -0.005 & 0.022 \\
\hline & & $(0.024)$ & $(0.024)$ & & $(0.022)$ & $(0.022)$ \\
\hline \multirow[t]{2}{*}{ External debt to GDP } & & & $0.004^{*}$ & & & $0.004 * * *$ \\
\hline & & & $(0.002)$ & & & $(0.001)$ \\
\hline Obs & 13,594 & 6,092 & 5,503 & 10,826 & 8,598 & 8,598 \\
\hline R-squared & 0.53 & 0.50 & 0.50 & 0.48 & 0.48 & 0.49 \\
\hline
\end{tabular}

Note: The dependent variables are the ratio of exchange rate-adjusted cross-border claims to the sum of exchange rate-adjusted cross-border claims and local claims in foreign currencies. All independent variables are lagged by one period. Heteroskedasticity-robust standard errors are clustered at the reportingcounterparty country levels. ${ }^{* * *}$ denotes $1 \%$ significant level, ${ }^{* *}$ denotes $5 \%$ significance level, and $*$ denotes $10 \%$ significance level. 
Table 10. Rebalancing between local and cross-border claims: IV approach

\begin{tabular}{|c|c|c|c|}
\hline \multirow[b]{2}{*}{ Explanatory variables } & \multicolumn{3}{|c|}{ Share of cross-border claims } \\
\hline & (I) & (II) & (III) \\
\hline \multirow[t]{2}{*}{ Log of uncertainty } & $1.513^{*}$ & $1.427^{*}$ & $1.735^{*}$ \\
\hline & $(0.884)$ & $(0.827)$ & $(0.980)$ \\
\hline \multirow[t]{2}{*}{ Real GDP growth } & $-0.079 * * *$ & -0.015 & 0.012 \\
\hline & $(0.019)$ & $(0.036)$ & $(0.034)$ \\
\hline \multirow[t]{2}{*}{ Stock market growth } & 0.004 & 0.001 & 0.003 \\
\hline & $(0.004)$ & $(0.003)$ & $(0.003)$ \\
\hline \multirow[t]{2}{*}{ CPI inflation } & -0.061 & -0.044 & -0.027 \\
\hline & $(0.037)$ & $(0.060)$ & $(0.069)$ \\
\hline \multirow[t]{2}{*}{ Policy rate } & $-0.071 * * *$ & $-0.080 * *$ & $-0.081 *$ \\
\hline & $(0.024)$ & $(0.032)$ & $(0.047)$ \\
\hline \multirow[t]{2}{*}{ Nominal exchange rate growth } & $-0.006^{* *}$ & $-0.007 *$ & $-0.007 *$ \\
\hline & $(0.003)$ & $(0.004)$ & $(0.004)$ \\
\hline \multirow[t]{2}{*}{ Private credit growth } & & -0.013 & 0.007 \\
\hline & & $(0.021)$ & $(0.018)$ \\
\hline \multirow[t]{2}{*}{ External debt to GDP } & & & 0.003 \\
\hline & & & $(0.002)$ \\
\hline Cragg-Donald Wald F-statistic & 207.18 & 321.86 & 256.47 \\
\hline $\begin{array}{l}\text { Stock-Yogo weak identification } \\
\text { test } 5 \% \text { critical values }\end{array}$ & 16.38 & 16.38 & 16.38 \\
\hline Obs & 24,420 & 14,690 & 14,101 \\
\hline R-squared & 0.48 & 0.48 & 0.50 \\
\hline
\end{tabular}

Note: The dependent variables are the ratio of exchange rate-adjusted cross-border claims to the sum of exchange rate-adjusted cross-border claims and local claims in foreign currencies. All independent variables are lagged by one period. Heteroskedasticity-robust standard errors are clustered at the reporting-counterparty country levels. ${ }^{* *}$ denotes $1 \%$ significant level, $* *$ denotes $5 \%$ significance level, and $*$ denotes $10 \%$ significance level. 
Table 11. Rebalancing between local and cross-border claims: Safe vs. risky borrowers

\begin{tabular}{lccc}
\hline & \multicolumn{3}{c}{ Share of cross-border claims } \\
\cline { 2 - 4 } Explanatory variables & $(\mathrm{I})$ & $(\mathrm{II})$ & $(\mathrm{III})$ \\
\hline Log of uncertainty & $0.497^{*}$ & $0.852^{* * *}$ & $0.734^{* *}$ \\
Log of uncertainty & $(0.262)$ & $(0.322)$ & $(0.299)$ \\
X counterparty EM dummy & $-0.427^{*}$ & $-0.909^{* * *}$ & $-0.901^{* * *}$ \\
Real GDP growth & $(0.256)$ & $(0.345)$ & $(0.336)$ \\
& $-0.089^{* * *}$ & $-0.060^{*}$ & -0.012 \\
Stock market growth & $(0.020)$ & $(0.031)$ & $(0.025)$ \\
& -0.002 & -0.002 & -0.001 \\
CPI inflation & $(0.001)$ & $(0.002)$ & $(0.002)$ \\
& -0.054 & $-0.121^{* *}$ & -0.090 \\
Policy rate & $(0.037)$ & $(0.058)$ & $(0.059)$ \\
& $-0.048^{* *}$ & $-0.054^{* *}$ & $-0.044^{*}$ \\
Nominal exchange rate growth & $(0.020)$ & $(0.025)$ & $(0.026)$ \\
& $-0.007^{* *}$ & $-0.010^{* *}$ & -0.008 \\
Private credit growth & $(0.003)$ & $(0.005)$ & $(0.005)$ \\
External debt to GDP & & -0.025 & 0.004 \\
Obs & & $(0.019)$ & $(0.018)$ \\
R-squared & & & $0.004^{* * *}$ \\
\hline
\end{tabular}

Note: The dependent variables are the ratio of exchange rate-adjusted cross-border claims to the sum of exchange rate-adjusted cross-border claims and local claims in foreign currencies. All independent variables are lagged by one period. Heteroskedasticity-robust standard errors are clustered at the reporting-counterparty country levels. ${ }^{* * *}$ denotes $1 \%$ significant level, ${ }^{* *}$ denotes $5 \%$ significance level, and $*$ denotes $10 \%$ significance level 


\section{Appendix A. Additional Figures and Tables}

Figure A.1. Country-specific uncertainty index

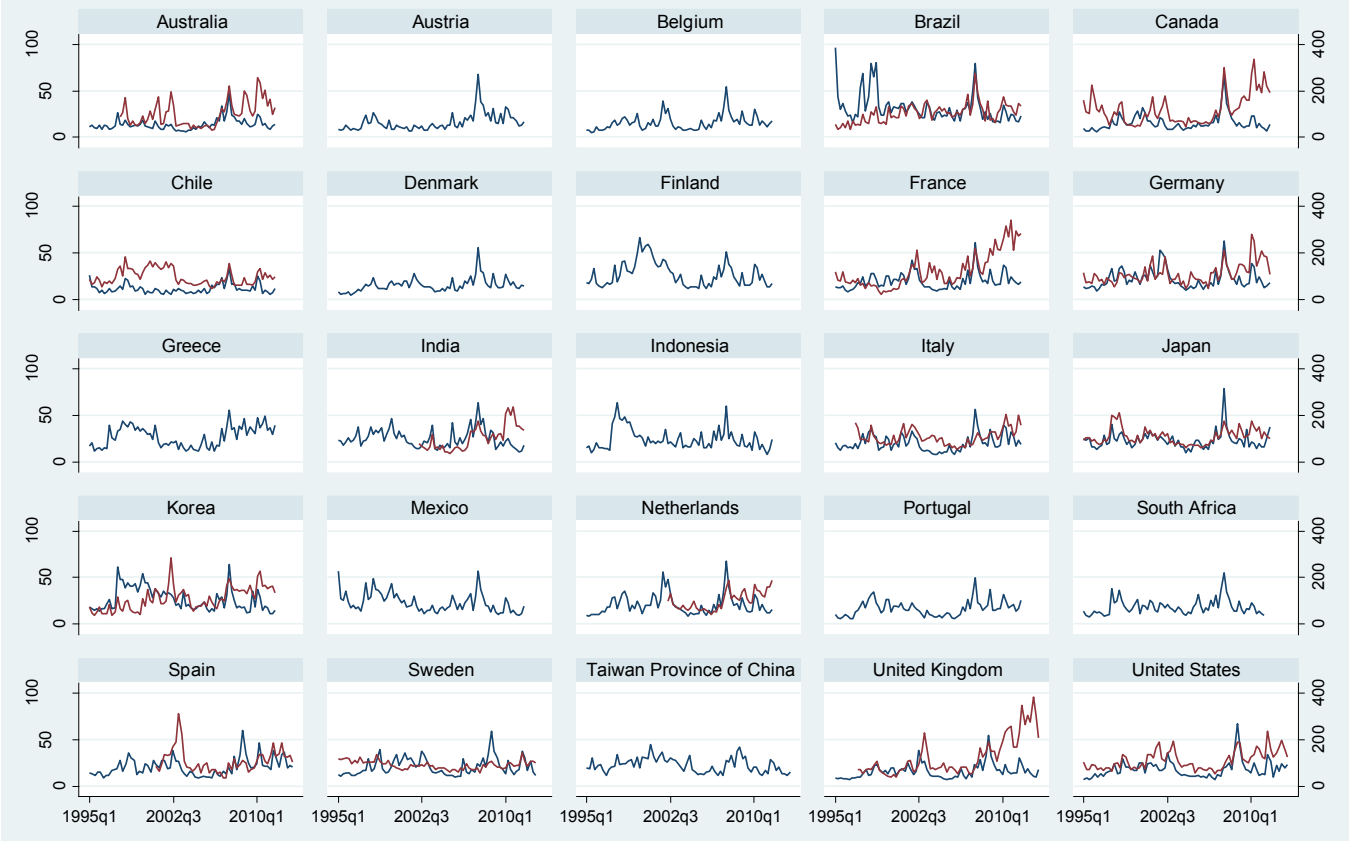


Table A.1. Event classification

\begin{tabular}{c|cc}
\hline & An increase & A decrease \\
\hline Gross inflows & Surge & Stops \\
Gross outflows & Flight & Retrenchment \\
\hline
\end{tabular}


Table A.2. List of countries in the final sample

\begin{tabular}{|c|c|c|c|}
\hline Source countries & $\begin{array}{c}=1 \text { if advanced } \\
\text { economy }\end{array}$ & Recipient countries & $\begin{array}{c}=1 \text { if advanced } \\
\text { economy }\end{array}$ \\
\hline Australia & 1 & Argentina & 0 \\
\hline Austria & 1 & Australia & 1 \\
\hline Belgium & 1 & Austria & 1 \\
\hline Brazil & 0 & Belgium & 1 \\
\hline Canada & 1 & Brazil & 0 \\
\hline Chile & 0 & Bulgaria & 0 \\
\hline Denmark & 1 & Canada & 1 \\
\hline Finland & 1 & Chile & 0 \\
\hline France & 1 & China & 0 \\
\hline Germany & 1 & Colombia & 0 \\
\hline Greece & 1 & Czech Republic & 1 \\
\hline India & 0 & Denmark & 1 \\
\hline Indonesia & 0 & Estonia & 1 \\
\hline Italy & 1 & Finland & 1 \\
\hline Japan & 1 & France & 1 \\
\hline Korea & 1 & Germany & 1 \\
\hline Mexico & 0 & Greece & 1 \\
\hline Netherlands & 1 & Hungary & 0 \\
\hline Portugal & 1 & India & 0 \\
\hline South Africa & 0 & Indonesia & 0 \\
\hline Spain & 1 & Israel & 1 \\
\hline Sweden & 1 & Italy & 1 \\
\hline Taiwan & 1 & Japan & 1 \\
\hline United Kingdom & 1 & Korea & 1 \\
\hline \multirow[t]{26}{*}{ United States } & 1 & Latvia & 0 \\
\hline & & Lithuania & 0 \\
\hline & & Malaysia & 0 \\
\hline & & Mexico & 0 \\
\hline & & Netherlands & 1 \\
\hline & & New Zealand & 1 \\
\hline & & Norway & 1 \\
\hline & & Pakistan & 0 \\
\hline & & Peru & 0 \\
\hline & & Philippines & 0 \\
\hline & & Poland & 0 \\
\hline & & Portugal & 1 \\
\hline & & Romania & 0 \\
\hline & & Russia & 0 \\
\hline & & Slovak Republic & 1 \\
\hline & & Slovenia & 1 \\
\hline & & South Africa & 0 \\
\hline & & Spain & 1 \\
\hline & & Sweden & 1 \\
\hline & & Taiwan & 1 \\
\hline & & Thailand & 0 \\
\hline & & Turkey & 0 \\
\hline & & Ukraine & 0 \\
\hline & & United Kingdom & 1 \\
\hline & & United States & 1 \\
\hline & & Venezuela & 0 \\
\hline
\end{tabular}


Table A.3. Before and after the Global Financial Crisis: Economic policy uncertainty

\begin{tabular}{lcccc}
\hline & \multicolumn{2}{c}{ Growth of claims (outflows) } & \multicolumn{2}{c}{ Growth of liabilities (inflows) } \\
& (I) & (II) & (III) & $($ IV) \\
\cline { 2 - 5 } & $\begin{array}{c}\text { Before the GFC } \\
(1995 \mathrm{Q} 1-2007 \mathrm{Q} 2)\end{array}$ & $\begin{array}{c}\text { After the GFC } \\
(2007 \mathrm{Q}-2012 \mathrm{Q} 4)\end{array}$ & $\begin{array}{c}\text { Before the GFC } \\
(1995 \mathrm{Q} 1-2007 \mathrm{Q} 2)\end{array}$ & $\begin{array}{c}\text { After the GFC } \\
(2007 \mathrm{Q}-2012 \mathrm{Q})\end{array}$ \\
\hline Log of uncertainty & $-2.841^{* *}$ & $-2.616^{*}$ & -0.827 & $-6.026^{* * *}$ \\
& $(1.289)$ & $(1.521)$ & $(1.348)$ & $(2.225)$ \\
Real GDP growth & $0.909^{* * *}$ & $1.080^{* *}$ & 0.593 & 0.820 \\
& $(0.297)$ & $(0.473)$ & $(0.552)$ & $(0.647)$ \\
Stock market growth & 0.008 & 0.062 & $-0.142^{* *}$ & $0.187^{* * *}$ \\
& $(0.033)$ & $(0.045)$ & $(0.068)$ & $(0.072)$ \\
CPI inflation & -0.183 & 0.078 & -0.202 & 0.311 \\
& $(0.536)$ & $(0.694)$ & $(1.056)$ & $(0.748)$ \\
Policy rate & 0.177 & $0.438^{* *}$ & 0.213 & 0.057 \\
& $(0.179)$ & $(0.214)$ & $(0.141)$ & $(0.226)$ \\
Nominal exchange rate & 0.003 & -0.063 & 0.259 & 0.057 \\
growth & $(0.079)$ & $(0.105)$ & $(0.167)$ & $(0.147)$ \\
\hline Obs & 11,578 & 9,559 & 11,126 & 8,998 \\
R-squared & 0.11 & 0.13 & 0.12 & 0.14 \\
\hline
\end{tabular}

Note: The dependent variables are the growth rate of exchange rate-adjusted cross-border claims in column (I) to (II) and the growth rate of exchange rate-adjusted cross-border liabilities in column (III) to (IV). All independent variables are lagged by one period. Heteroskedasticity-robust standard errors are clustered at the reporting-counterparty country levels. ${ }^{* * *}$ denotes $1 \%$ significant level, $* *$ denotes $5 \%$ significance level, and $*$ denotes $10 \%$ significance level. 
Table A.4. Rebalancing between local and cross-border claims: Alternative measure of uncertainty (idiosyncratic stock market volatility)

\begin{tabular}{lccc}
\hline & \multicolumn{3}{c}{ Share of cross-border claims } \\
\cline { 2 - 4 } Explanatory variables & $(\mathrm{I})$ & $(\mathrm{II})$ & $(\mathrm{III})$ \\
\hline Log of uncertainty & $0.012^{*}$ & $0.018^{* *}$ & $0.015^{* *}$ \\
& $(0.007)$ & $(0.008)$ & $(0.007)$ \\
Real GDP growth & $-0.083^{* * *}$ & $-0.060^{*}$ & -0.009 \\
& $(0.020)$ & $(0.031)$ & $(0.025)$ \\
Stock market growth & -0.002 & -0.001 & -0.001 \\
& $(0.001)$ & $(0.002)$ & $(0.002)$ \\
CPI inflation & $-0.065^{*}$ & $-0.135^{* *}$ & -0.099 \\
& $(0.039)$ & $(0.059)$ & $(0.062)$ \\
Policy rate & $-0.045^{* *}$ & $-0.043^{*}$ & -0.034 \\
Nominal exchange rate growth & $(0.020)$ & $(0.024)$ & $(0.026)$ \\
& $-0.008^{* *}$ & $-0.010^{* *}$ & -0.007 \\
Private credit growth & $(0.004)$ & $(0.005)$ & $(0.005)$ \\
& & -0.029 & 0.001 \\
External debt to GDP & & $(0.020)$ & $(0.019)$ \\
& & & $0.004 * * *$ \\
Obs & & 14,690 & $(0.001)$ \\
R-squared & 24,420 & 0.50 & 14,101 \\
\hline
\end{tabular}

Note: The dependent variables are the ratio of exchange rate-adjusted cross-border claims to the sum of exchange rate-adjusted cross-border claims and local claims in foreign currencies. All independent variables are lagged by one period. Heteroskedasticity-robust standard errors are clustered at the reporting-counterparty country levels. $* * *$ denotes $1 \%$ significant level, $* *$ denotes $5 \%$ significance level, and $*$ denotes $10 \%$ significance level. 
Table A.5. Rebalancing between local and cross-border claims: IV approach with alternative measures of uncertainty

\begin{tabular}{|c|c|c|c|c|c|c|}
\hline \multirow{3}{*}{ Explanatory variables } & \multicolumn{6}{|c|}{ Share of cross-border claims } \\
\hline & (I) & (II) & (III) & (IV) & $(\mathrm{V})$ & (VI) \\
\hline & \multicolumn{3}{|c|}{ Economic policy uncertainty } & \multicolumn{3}{|c|}{ Idiosyncratic stock market volatility } \\
\hline \multirow[t]{2}{*}{ Log of uncertainty } & $1.194 *$ & $1.499 *$ & $1.392 *$ & $0.102 *$ & $0.098 *$ & $0.124 *$ \\
\hline & $(0.683)$ & $(0.798)$ & $(0.817)$ & $(0.060)$ & $(0.057)$ & $(0.067)$ \\
\hline \multirow[t]{2}{*}{ Real GDP growth } & $-0.103 * * *$ & $-0.160 * * *$ & $-0.085^{* *}$ & $-0.073 * * *$ & 0.032 & 0.069 \\
\hline & $(0.024)$ & $(0.048)$ & $(0.039)$ & $(0.018)$ & $(0.058)$ & $(0.061)$ \\
\hline \multirow[t]{2}{*}{ Stock market growth } & -0.002 & 0.002 & 0.002 & 0.009 & 0.007 & 0.009 \\
\hline & $(0.002)$ & $(0.003)$ & $(0.003)$ & $(0.007)$ & $(0.006)$ & $(0.007)$ \\
\hline \multirow[t]{2}{*}{ CPI inflation } & $-0.083 * *$ & $-0.146 * *$ & -0.125 & $-0.099 *$ & 0.004 & 0.033 \\
\hline & $(0.036)$ & $(0.072)$ & $(0.079)$ & $(0.052)$ & $(0.079)$ & $(0.095)$ \\
\hline \multirow[t]{2}{*}{ Policy rate } & $-0.046^{* *}$ & $-0.050 * *$ & $-0.044^{*}$ & $-0.072 * * *$ & $-0.090 * *$ & $-0.098 *$ \\
\hline & $(0.020)$ & $(0.024)$ & $(0.025)$ & $(0.025)$ & $(0.037)$ & $(0.055)$ \\
\hline \multirow[t]{2}{*}{ Nominal exchange rate growth } & $-0.009 * *$ & $-0.015^{* *}$ & $-0.012 *$ & $-0.009 * *$ & $-0.008^{*}$ & $-0.011 *$ \\
\hline & $(0.004)$ & $(0.006)$ & $(0.006)$ & $(0.004)$ & $(0.005)$ & $(0.006)$ \\
\hline \multirow[t]{2}{*}{ Private credit growth } & & -0.003 & 0.024 & & $-0.021 *$ & -0.009 \\
\hline & & $(0.023)$ & $(0.021)$ & & $(0.019)$ & $(0.020)$ \\
\hline \multirow[t]{2}{*}{ External debt to GDP } & & & $0.004 * * *$ & & & 0.003 \\
\hline & & & $(0.001)$ & & & $(0.002)$ \\
\hline Cragg-Donald Wald F-statistic & 518.58 & 459.28 & 425.07 & 105.84 & 150.77 & 112.59 \\
\hline $\begin{array}{l}\text { Stock-Yogo weak identification } \\
\text { test } 5 \% \text { critical values }\end{array}$ & 16.38 & 16.38 & 16.38 & 16.38 & 16.38 & 16.38 \\
\hline Obs & 19,617 & 13,271 & 13,057 & 24,420 & 14,690 & 14,101 \\
\hline R-squared & 0.50 & 0.48 & 0.49 & 0.50 & 0.50 & 0.51 \\
\hline
\end{tabular}

Note: The dependent variables are the ratio of exchange rate-adjusted cross-border claims to the sum of exchange rate-adjusted cross-border claims and local claims in foreign currencies. All independent variables are lagged by one period. Heteroskedasticity-robust standard errors are clustered at the reportingcounterparty country levels. ${ }^{* * *}$ denotes $1 \%$ significant level, ${ }^{* *}$ denotes $5 \%$ significance level, and $*$ denotes $10 \%$ significance level. 


\section{Appendix B. Additional exercise on the rebalancing channel of global banks}

To test the rebalancing hypothesis, we have analyzed the behavior of the share of crossborder claims of global banks to total claims (the sum of cross-border claims and local claims in local currencies) of the same set of global banks. However, the BIS LBS provides information on the amount of local claims by global banks in local currencies only after 2012, forcing us to miss a substantial part of local lending by the global banks. Thus, we have used only local claims in foreign currencies when constructing $s_{i, j, t}$ in equation (3) to maintain consistency in creating a new variable.

To complement the analysis above, we construct a new variable measuring the share of cross-border claims of global banks to domestic claims of the banking system as a whole. While total domestic claims of the banking system include local claims in domestic currencies, they not only cover global banks that report their cross-border claims, but domestic banks without any cross-border claims. To the extent that the global banks account for a large share of domestic banking system, the new variable provides a reasonable measure of the share of crossborder claims. If the share of global banks is relatively small to the domestic banking system, our proxy could be subject to substantial measurement errors. Thus, we view this additional exercise as a complementary analysis to a more formal analysis in the main text.

We obtain domestic bank claims (line 32) from the IMF International Financial Statistics Depository Corporations Survey. Because the BIS LBS includes bank claims on both the private and public sectors, we also use total domestic claims rather than domestic claims on the private sector (line 22d). Because cross-border claims are measured in the U.S. dollar, we convert the cross-border claims into local currencies. The share of cross-border claims to total domestic claims is computed as:

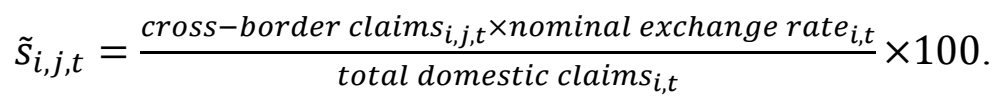

For most countries in the sample, total domestic claims at a quarterly frequency in a consistent manner are available from the IFS since 2001. To confirm that our results are not 
driven by the analysis of a shorter sample period, we repeat the baseline analysis using the data since 2001 and find that our main findings hardly change. ${ }^{28}$

$$
\tilde{s}_{i, j, t}=\alpha_{j, t}+\beta X_{i, t-1}+\gamma U N C_{i, t-1}+\varepsilon_{i, j, t}
$$

Table B.1 show the results from estimating equation (7) by using both measures of uncertainty, as well as using an IV approach described in the main text and adding the interaction term to denote the recipient country status (emerging vs. advanced). Although this analysis could be subject to measurement errors, it still provides confirm the baseline results.

${ }^{28}$ For example, the coefficient on the lagged uncertainty term is still negative and significant at $5 \%$ level. The results are available upon request. 
Table B.1. Rebalancing between domestic and cross-border lending: Using an alternative share of cross-border claims

\begin{tabular}{|c|c|c|c|c|c|c|}
\hline \multirow{3}{*}{ Explanatory variables } & (I) & (II) & (III) & (IV) & $(\mathrm{V})$ & (VI) \\
\hline & \multicolumn{3}{|c|}{ Stock market volatility } & \multicolumn{3}{|c|}{ Economic policy uncertainty } \\
\hline & OLS & IV & OLS interaction & OLS & IV & OLS interaction \\
\hline \multirow[t]{2}{*}{ Log of uncertainty } & $3.012 * * *$ & $9.125 * * *$ & $4.979 * * *$ & $2.201 * * *$ & $2.341 * *$ & $3.082 * * *$ \\
\hline & $(0.670)$ & $(1.833)$ & (1.108) & $(0.604)$ & $(1.036)$ & $(0.909)$ \\
\hline Log of uncertainty & & & $-4.830 * * *$ & & & $-2.149 * * *$ \\
\hline$X$ counterparty EM dummy & & & $(1.247)$ & & & $(0.808)$ \\
\hline \multirow[t]{2}{*}{ Real GDP growth } & $-0.207 *$ & $-0.248 * *$ & $-0.225^{*}$ & $-0.675 * * *$ & $-0.449 * * *$ & $-0.675 * * *$ \\
\hline & $(0.121)$ & $(0.119)$ & $(0.120)$ & $(0.160)$ & $(0.116)$ & $(0.159)$ \\
\hline \multirow[t]{2}{*}{ Stock market growth } & $0.019 * * *$ & $0.010^{* *}$ & $0.018^{* * *}$ & $0.016^{* * *}$ & $0.003)$ & $0.016^{* * *}$ \\
\hline & $(0.006)$ & $(0.005)$ & $(0.006)$ & $(0.006)$ & $(0.004)$ & $(0.006)$ \\
\hline \multirow[t]{2}{*}{ CPI inflation } & $-2.975 * * *$ & $-2.845 * * *$ & $-2.953 * * *$ & $-3.082 * * *$ & $-3.067 * * *$ & $-3.058 * * *$ \\
\hline & $(0.573)$ & $(0.555)$ & $(0.567)$ & $(0.730)$ & $(0.765)$ & $(0.723)$ \\
\hline \multirow[t]{2}{*}{ Policy rate } & $-0.482 * * *$ & $-0.688 * * *$ & $-0.516 * * *$ & $-0.256 * * *$ & $-0.309 * * *$ & $-0.266 * * *$ \\
\hline & $(0.112)$ & $(0.139)$ & $(0.120)$ & $(0.082)$ & $(0.096)$ & $(0.085)$ \\
\hline \multirow[t]{2}{*}{ Nominal exchange rate growth } & $-0.150 * * *$ & $-0.131 * * *$ & $-0.151 * * *$ & $-0.162 * * *$ & $-0.138 * * *$ & $-0.162 * * *$ \\
\hline & $(0.031)$ & $(0.027)$ & $(0.031)$ & $(0.037)$ & $(0.032)$ & $(0.037)$ \\
\hline \multirow[t]{2}{*}{ Private credit growth } & -0.085 & -0.065 & -0.09 & $-0.185 * * *$ & $-0.136^{* * *}$ & $-0.185^{* * *}$ \\
\hline & $(0.059)$ & $(0.058)$ & $(0.059)$ & $(0.048)$ & $(0.037)$ & $(0.048)$ \\
\hline \multirow[t]{2}{*}{ External debt to GDP } & $-0.018 * * *$ & $-0.023 * * *$ & $-0.019 * * *$ & $-0.016^{* * *}$ & $-0.013 * * *$ & $-0.016^{* * *}$ \\
\hline & $(0.005)$ & $(0.005)$ & $(0.005)$ & $(0.005)$ & $(0.004)$ & $(0.005)$ \\
\hline Obs & 17,029 & 17,029 & 17,029 & 14,213 & 14,213 & 14,213 \\
\hline R-squared & 0.20 & 0.22 & 0.20 & 0.23 & 0.19 & 0.23 \\
\hline
\end{tabular}

